

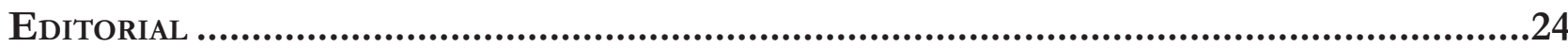

O Direito na fronteira da razão: Psicologia, neurociência e economia comportamental................... 24 Patrícia Perrone Campos Mello e Sergio Nojiri

I. NeURodireito: COGNIÇão, EMOÇÃo, JUÍZOS MORAIS E CIÊNCIA ..........................................26

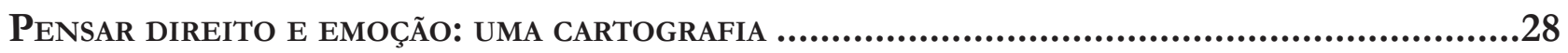

Nevita Maria Pessoa de Aquino Franca Luna

Neurodireito: o início, o fim E O MEIO

Carlos Marden e Leonardo Martins Wykrota

ENSAIO JURÍDICO SOBRE A RACIONALIDADE HUMANA: MAIORES, CAPAZES E IRRACIONAIS

André Perin Schmidt Neto e Eugênio Facchini Neto

DIVERGÊNCIAS DE PRINCÍPIO: ARGUMENTOS JURÍDICOS E MORAIS EM UM CENÁRIO DE DESACORDOS SOCIAIS

André Matos de Almeida Oliveira, Pâmela de Rezende Côrtes e Leonardo Martins Wykrota

CONSILIÊNCIA E A POSSIBILIDADE DO NEURODIREITO: DA DESCONFIANÇA À RECONCILIAÇÃO DISCIPLINAR.....

Thaís de Bessa Gontijo de Oliveira e Renato César Cardoso

MODELOS DE MORALIDADE

Molly J. Crockett

A INFELIZ BUSCA POR FELICIDADE No DiREITo

Úrsula Simões da Costa Cunha Vasconcellost, Noel Struchiner e Ivar Hannikainen

Além da liberdade: PersPeCtivas Em Nietzsche.

Lucas Costa de Oliveira

A mediaÇão de CONFlitos SOb a PERSPECTIVA do DESENVOLVIMENTO HUMANO: AS CONTRIBUIÇÕES DA PSICOLOGIA POSITIVA

Simone de Biazzi Ávila Batista da Silveira e Deise Brião Ferraz

Neuroimagiologia e aValiação de ResPonsabilidade

Nicole A. Vincent 
ANÁLISE CRÍTICA DA ORIENTAÇÃO DE CIDADÃOS COMO MÉTODO PARA OTIMIZAR DECISÕES PÚBLICAS POR MEIO DA TÉCNICA NUDGE.

Luciana Cristina Souza, Karen Tobias França Ramos e Sônia Carolina Romão Viana Perdigão

Políticas públicas e o deVer de monitoramento: “LEVANdo os Direitos A SÉrio". .252 Ana Paula de Barcellos

Nudges E POLÍticas PÚblicas: uM MECANISMO DE COMBATE AO TRABALHO EM CONDIÇÃo ANÁLOGA À DE ESCRAVO .267

Amanda Carolina Souza Silva, Débhora Renata Nunes Rodrigues e Saul Duarte Tibaldi

REDUZINDO A TRIBUTAÇÃO COGNITIVA: LIÇÕES COMPORTAMENTAIS PARA A DIMINUIÇÃO DOS EFEITOS PSICOLÓGICOS ADVERSOS DA POBREZA.............................................................288 Leandro Novais e Silva, Luiz Felipe Drummond Teixeira, Gabriel Salgueiro Soares e Otávio Augusto Andrade Santos

Políticas PÚBLICAS EM SUICÍDIO: DO PATERNALISMO CLÁSSICO AO PATERNALISMO LIBERTÁRIO E NUDGING

Davi de Paiva Costa Tangerino, Gabriel Cabral e Henrique Olive

Nudges COMO POLÍticA PÚbliCA PARA AUMENTAR O ESCASSO NÚMERO DE DOADORES DE ÓRGÃos PARA TRANSPLANTE

Roberta Marina Cioatto e Adriana de Alencar Gomes Pinheiro

Os PROGRAMAS DE INTEGRIDADE PARA CONTRATAÇÃO COM A ADMINISTRAÇÃO PÚBLICA ESTADUAL: NUDGE OU OBRIGAÇÃo LEGAL? UM OLHAR SOBRE AS DUAS PERSPECTIVAS .386

Cíntia Muniz Rebouças de Alencar Araripe e Raquel Cavalcanti Ramos Machado

Paternalismo libertário e Proteção JURídica do AMbiente: POR QUe PROTEger o AMBIENTE TAMBÉM DEVE SER PROTEGER AS LIBERDADES?

Mariana Carvalho Victor Coelho e Patryck de Araujo Ayala

Políticas PÚblicas baseadas EM EVIdÊNCIAS COMPORTAMENTAIS: REFLEXões A PARTIR do Projeto de Lei 488/2017 do Senado

Pâmela de Rezende Côrtes, André Matos de Almeida Oliveira e Fabiano Teodoro de Rezende Lara

III. ECONOMIA COMPORTAMENTAL: VIESES COGNITIVOS E POLÍTICAS PÚBLICAS .455

ECONOMIA COMPORTAMENTAL E DIREITO: A RACIONALIDADE EM MUDANÇA Marcia Carla Pereira Ribeiro e Victor Hugo Domingues

VIESES COGNITIVOS E DESENHO DE POLÍTICAS PÚBLICAS 
A neurociênCia da moralidade na tomada de DeCisões Jurídicas Complexas e No DESENHO DE POLÍTICAS PÚBLICAS

Erik Navarro Wolkart

Desvio de CARÁter ou SIMPLESMENTE HUMANO? ECONOMIA COMPORTAMENTAL APLICADA AO COMPORTAMENTO DESONESTO

Diana Orghian, Gabriel Cabral, André Pinto e Alessandra Fontana

Políticas Públicas e a ConcretizaÇão de direitos sociais: TOMAdA DE DECisão, ARQUITETURA DE ESCOLHAS E EFETIVIDADE

Ana Elizabeth Neirão Reymão e Ricardo dos Santos Caçapietra

BEHAVIORAL ECONOMICS E DIREITO DO CONSUMIDOR: NOVAS PERSPECTIVAS PARA O ENFRENTAMENTO DO SUPERENDIVIDAMENTO .568

Samir Alves Daura

A EDUCAÇÃo FORMAL PARA O CONSUMO É GARANTIA PARA UMA PRESENÇA REFLETIDA DO CONSUMIDOR NO MERCADO? UMA ANÁLISE COM BASE NA BEHAVIORAL LAW AND ECONOMICS (ECONOMIA COMPORTAMENTAL) 600

Marcia Carla Pereira Ribeiro e Edson Mitsuo Tiujo

LIBET, DETERMINISMO E CONSUMO: AS INFLUÊNCIAS DO MARKETING E A RELEVÂNCIA DA DELIBERAÇÃo CONSCIENTE NA SUPERAÇÃo CONDICIONAL DE HÁBITOS DE CONSUMO PERIGOSOS616 Émilien Vilas Boas Reis e Leonardo Cordeiro de Gusmão

CiÊNCIA DO DIREITO TRIBUTÁRIO, ECONOMIA COMPORTAMENTAL E EXTRAFISCALIDADE. .640 Hugo de Brito Machado Segundo

IV. CoMportamento JUdiCiAL: INFLUÊNCIA DE FATORES EXTRAJURÍDicos .660

FATORES METAPROCESSUAIS E SUAS INFLUÊNCIAS PARA A FORMAÇÃo DA DECISÃo JUDICIAL .662 Rogério Roberto Gonçalves de Abreu, Lúcio Grassi de Gouveia e Virgínia Colares

“A VIDA COMO ELA É": COMPORTAMENTO ESTRATÉGICO NAS CORTES Patrícia Perrone Campos Mello

A COMPOSIÇÃo do ÓRGão COLEGIAdo E SEUS EFEITOS NA TOMADA DE DECISÃo .720 André Garcia Leão Reis Valadares

Das 11 ilhas ao centro do arquipélago: os superpoderes do Presidente do STF DURANTE O RECESSO JUDICIAL E FÉRIAS .741 José Mário Wanderley Gomes Neto e Flávia Danielle Santiago Lima 
RAZÃo, EMOÇÃo E DELIBERAÇÃO: AS ADEQUAÇÕES REgIMENTAIS do SUPERIOR TribUNAL DE JUSTIÇA PARA A FORMAÇÃo DE PRECEDENTES EFICAZES

Peter Panutto e Lana Olivi Chaim

Heurística de ancoragem e fiXaÇÃo de danos morais em JUizados especiais Cíveis no Rio DE JANEIRO: UMA NOVA ANÁLISE 778

Fernando Leal e Leandro Molhano Ribeiro

LA PROTECCIÓN DE LOS DERECHOS POLÍTICOS FRENTE A LAS FUNCIONES DISCIPLINARIAS DE LAS AUTORIDADES ADMINISTRATIVAS: SUBSIDIARIEDAD Y DEFERENCIA EN EL SISTEMA INTERAMERICANO DE DERECHOS HUMANOS Jorge Ernesto Roa Roa

V. A influênCia do gÊNERo no PROCESSO DECisório JUdiCial

Como os Juízes decidem os Casos de estupro? ANALISANDo SENTENÇAS SOb A PERSPECTIVA DE VIESES E ESTEREÓTIPOS DE GÊNERO 826 Gabriela Perissinotto de Almeida e Sérgio Nojiri

GÊNERO E COMPORTAMENTO JUDICIAL NO SUPREMO TRIBUNAL FEDERAL: OS MINISTROS CONFIAM MENOS EM RELATORAS MULHERES?

Juliana Cesario Alvim Gomes, Rafaela Nogueira e Diego Werneck Arguelhes

Hércules, Hermes e a Pequena Sereia: uma reflexão sobre estereótipos de gênero, SUBPRESENTAÇÃo DAS MULHERES NOS TRIBUNAIS E (I)LEGITIMIDADE DEMOCRÁTICA DO PODER JUDICIÁRIO. .878 Jane Reis Gonçalves Pereira e Renan Medeiros de Oliveira

Prisão Cautelar de gestantes: análise do Fundamento filosófico da decisão do Habeas CoRpus N. 143.641 912

Artur César Souza e Giovania Tatibana de Souza

VI. Neurodireito APlicado ao direito E Ao Processo PENAL....................................926

CÉREbros QUe PUNEM: UMA REVISÃo CRÍTICA DA NEURoCIÊNCIA DA PUNIÇÃo .....................928 Ricardo de Lins e Horta

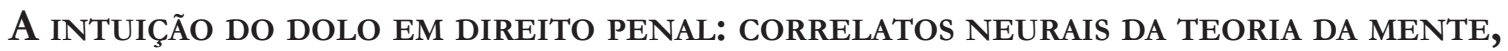
RACIOCÍNIO INDUTIVO E A GARANTIA DA CONVICÇÃO JUSTIFICADA. .946 Thiago Dias de Matos Diniz e Renato César Cardoso

As COMUNIDADES EPISTÊMICAS PENAIS E A PRODUÇÃo LEGISLATIVA EM MATÉRIA CRIMINAL..... 961 Stéphane Enguéléguélé 
DELINQUÊNCIA JUVENIL: RELAÇÕES ENTRE DESENVOLVIMENTO, FUNÇÕES EXECUTIVAS E COMPORTAMENTO SOCIAL NA ADOLESCÊNCIA .

André Vilela Komatsu, Rafaelle CS Costa e Marina Rezende Bazon

Límites TEMPORALES A LAS PENAS PRIVATIVAS DE LIBERTAD ATENDIENDO AL DESARROLLO PSICOSOCIAL.

Silvio Cuneo Nash

NEURolaw E AS PERSPECTIVAS PARA UMA ANÁLISE OBJETIVA DO COMPORTAMENTO SUGESTIONADO: REPERCUSSÃO DAS FALSAS MEMÓRIAS NA ESFERA PENAL

Mariana Dionísio de Andrade, Marina Andrade Cartaxo e Rafael Gonçalves Mota

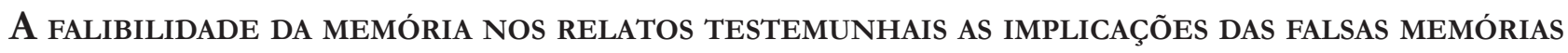
NO CONTEXTO DOS CRIMES CONTRA A DIGNIDADE SEXUAL

Caroline Navas Viana

A (IR)REPETIBILIDADE dA PROVA PENAL DEPENDENTE DA MEMÓRIA: UMA DisCUSSÃo COM BASE NA PSICOLOGIA DO TESTEMUNHO. 1058

William Weber Cecconello, Gustavo Noronha de Avila e Lilian Milnitsky Stein 


\title{
Ensaio jurídico sobre a racionalidade humana: maiores, capazes e irracionais*
}

\section{Legal essay on human rationality: adult, capable and irrational}

\author{
André Perin Schmidt Neto** \\ Eugênio Facchini Neto***
}

Dizem que o homem é um animal racional. Tenho procurado a vida toda alguma evidência dessa afirmação. (Bertrand Russell)

* Recebido em 31/05/2018 Aprovado em 29/07/2018

** Doutor em Direito Comparado (Università Degli Studi di Firenze/Itália), Mestre em Direito Civil (Faculdade de Direito da Universidade de São Paulo - USP). Professor Titular dos Cursos de Graduação, Mestrado e Doutorado em Direito da PUC/RS. Professor e ex-diretor da Escola Superior da Magistratura/AJURIS. Desembargador do Tribunal de Justiça do Estado do Rio Grande do Sul/Brasil. E-mail: facchini@tirs.jus.br

*** Pós-doutor (Università degli Studio di Salerno/Itália). Doutor, Mestre, bolsista CAPES e especialista em Direito do Consumidor e Direitos Fundamentais (Universidade Federal do Rio Grande do Sul - UFRGS). Professor da Pontifícia Universidade Católica do Rio Grande do Sul (PUC/RS) onde coordena o Grupo de Estudos "Superendividamento: crédito e sociedade de consumo" e da Universidade do Vale do Rio dos Sinos (UNISINOS). Professor da Pós-Graduação Lato Sensu da UFRGS, PUCRS, UNISINOS, UNIRITTER, URI. Professor da Escola Superior da Magistratura/AJURIS, onde é pós-graduado. Membro da Comissão Especial de Defesa do Consumidor da Ordem dos Advogados do Brasil. Autor de livros e artigos jurídicos. Advogado em Porto Alegre/RS. E-mail: andre.schmidt.adv@ gmail.com

\section{Resumo}

$\mathrm{O}$ artigo discute o acerto da pressuposição de que pessoas maiores e capazes sempre agem livremente e realizam escolhas racionais, sendo, portanto, juridicamente responsáveis pelos seus comportamentos. O tema da racionalidade humana é revisitado com base nas noções científicas provenientes da psicologia comportamental e da economia comportamental. Insights oriundos dessas áreas demonstram como os processos psicológicos de tomada de decisão são complexos e nem sempre racionais. Processos mentais denominados de ajustamento, ancoragem, disponibilidade e representatividade são inconscientemente utilizados quando tomamos decisões. Características humanas como o superotimismo e a aversão a perdas, também, estão presentes. O resultado da conjunção desses fatores é que tomamos decisões que nem sempre passam pelo teste da racionalidade. Seres humanos são influenciáveis e sugestionáveis. Dominando determinadas técnicas, agentes econômicos induzem consumidores e outras pessoas vulneráveis a tomarem decisões que nem sempre consultam seus próprios interesses. Embora a ciência jurídica não possa prescindir do pressuposto da liberdade com responsabilidade, ligando consequências jurídicas a condutas aparentemente livres e desejadas, não pode o Direito desconhecer a fragilidade da base sobre a qual se assentam alguns institutos jurídicos, especialmente no campo da responsabilidade contratual e extracontratual. $\mathrm{O}$ artigo conclui apontando alguns efeitos jurídicos possíveis do reconhecimento desse déficit de racionalidade humana. A originalidade do artigo consiste em chamar a atenção dos juristas para os potenciais efeitos jurídicos da irracionalidade do agir humano, visando ampliar a proteção jurídica da pessoa humana. Utilizou-se o método dialético, lançando-se mão de pesquisa bibliográfica básica, visando sua aplicação, com abordagem qualitativa.

Palavras-chave: Psicologia e economia comportamentais. Irracionalidade humana. Efeitos jurídicos. 


\section{Abstract}

The article discusses the accuracy of the assumption that grown-up and capable people always act freely and make rational choices and are therefore legally responsible for their behavior. The theme of human rationality is revisited based on scientific notions from other areas of knowledge, especially behavioral psychology and behavioral economics. Insights from these areas demonstrate how psychological processes of decision making are complex and not always rational. Mental processes called adjustment, anchoring, availability, and representativeness are unconsciously used when making decisions. Human characteristics such as super-optimism and loss-aversion are also present. The result of the conjunction of these factors is that we make decisions that do not always pass the test of rationality. Human beings are influential and suggestible. By mastering certain techniques, economic agents induce consumers and other vulnerable people to make decisions that do not always consult their own interests. Although legal science can not give-away the presupposition of freedom with responsibility, linking legal consequences to seemingly free and desired conduct, law can not ignore the fragility of the basis on which some legal institutes are based, especially in the field of contractual and extracontractual liability. The article concludes by pointing out some possible legal effects of the recognition of this deficit of human rationality. The originality of the article is to draw the attention of jurists to the potential legal effects of the irrationality of human action, aiming to broaden the legal protection of the human person. The dialectical method was used in a bibliographic research, with a qualitative approach.

Keywords: Psychology and behavioral economics. Human irrationality. Legal effects.

\section{INTRODUÇÃo}

A pressuposição básica que subjaz aos mais variados institutos jurídicos consiste na premissa de que o ser humano maior e capaz caracteriza-se por sua liberdade e racionalidade. Como tal, é livre para escolher entre condutas a adotar. A escolha entre as diversas alternativas é fruto de uma reflexão racional. A consequência lógica é que ele pode ser responsabilizado pelo resultado de suas condutas, a ele podendo ser imputados os efeitos previstos em lei para cada segmento jurídico. Isso é válido para o direito penal, para o direito contratual, para a responsabilidade civil extracontratual, para o direito de família, e para os demais ramos do direito em que o comportamento de uma pessoa é relevante para a produção de efeitos jurídicos. Assim, por exemplo, no direito penal, toda a ideia de incriminação funda-se na percepção de que seres humanos têm a liberdade para praticar ou não um tipo penal. A infração penal, voluntariamente praticada, por ser reprovável, acarreta a sanção penal correspondente. Quem não tem imputabilidade não responde penalmente por seus atos. Igualmente não sofre juízo de reprovabilidade penal quem age sob coação irresistível. No direito contratual, só pessoas capazes, livres de qualquer coação, podem assumir obrigações negociais. Assumindo livremente determinada obrigação, fica-se obrigado a cumprir fielmente o que foi pactuado, oriundo de vontade externada - pacta sunt servanda. Classicamente, somente atos culposos (ou seja, voluntários ou negligentemente praticados) acarretavam a responsabilidade aquiliana de alguém. Somente por exceção - e em tempos mais recentes — se admitiu a responsabilidade objetiva de pessoas físicas, desconsiderando-se sua percepção anímica.

A própria noção de democracia se assenta nessa pressuposição: partidos e candidatos se apresentam ao eleitor com suas propostas; devidamente informado sobre elas, o eleitor racionalmente escolheria entre um deles, de forma livre; uma vez eleito, o agente político usaria o poder que lhe é inerente para fazer escolhas entre várias opções de políticas públicas ou de alternativas legislativas. Essas escolhas, feitas por seu representante político, igualmente vinculam e obrigam o cidadão.

O presente artigo, embora reconhecendo que tal pressuposição é imprescindível para a convivência 
jurídica em sociedades civilizadas, questiona os limites da ideia de que os seres humanos sempre tomam decisões livres e racionais.

Após analisar a forma clássica como a racionalidade e o livre-arbítrio ingressou nos institutos jurídicos, passando a constituir noção pressuposta e não mais discutida, sendo considerada inerente a qualquer manifestação de vontade de pessoas maiores e capazes, o artigo questiona o alcance de tal noção, com base nas contribuições oriundas de outras áreas do saber, como a psicologia comportamental e a economia comportamental. Na última parte do artigo, os autores discutem alguns impactos dessa relativização do livre-arbítrio no mundo jurídico, apontando determinados efeitos.

Quanto aos aspectos metodológicos, trata-se de uma pesquisa que vai da básica à aplicada, com abordagem qualitativa, sendo usado o método dialético ${ }^{1}$. No que se refere ao procedimento, utiliza-se a pesquisa bibliográfica.

\section{A racionalidade pREsSUPosta}

"Há momentos em que os homens são donos de seu fado. Não é dos astros, caro Brutus, a culpa, mas de nós mesmos, se nos rebaixamos ao papel de instrumentos". (Shakespeare, Júlio César, Ato 1, Cena II) ${ }^{2}$

Escrevendo em pleno humanismo renascentista era natural que Shakespeare colocasse na boca de seus personagens palavras representativas de noções correntes naquele período histórico. Vivia ele num período em que o homem, libertando-se do jugo de uma estreita visão religiosa de mundo, acreditava ser dono de seu destino, capaz de, pela razão, explicar o mundo e seus fenômenos. Já na época dos antigos romanos e, anteriormente, dos gregos, era relativamente corrente a ideia de que os homens eram quase que joguetes do destino, manipulado pelos humores dos deuses. Hoje, sabemos que os insondáveis mistérios do inconsciente comandam parte de nossas condutas - e impactam nossos destinos —; às vezes, a outra parte é comandada por estratégias de publicidade e marketing que, conhecedoras dos mecanismos anímicos do sugestionamento, influenciam nossos comportamentos. Parece que migramos de um determinismo comandado por deuses brincalhões, passamos por um livre-arbítrio consentido pelo Deus cristão, e chegamos, segundo alguns, a um determinismo identificado pela deusa-ciência: a mente comandada pelo inconsciente; comportamentos comandados por marqueteiros, publicitários, youtubers e diversos outros formadores de opiniões.

Ao contrário dos outros animais, que agem por instinto, o ser humano é o único ser capaz de tomar decisões racionais. ${ }^{3}$ Essa é a premissa sobre a qual foi construída a civilização tal qual a conhecemos. Após

1 "Método dialético (Hegel, G.): empregado em pesquisa qualitativa, considera que os fatos não podem ser considerados fora de um contexto social; as contradições se transcendem dando origem a novas contradições que requerem soluções" - segundo ALMEIDA, Mauricio B. Noções básicas sobre metodologia de pesquisa científica. Disponível em: <http://mba.eci.ufmg.br/downloads/ metodologia.pdf>. Acesso em: 21 jul. 2018. No caso em tela, parte-se de pressuposição (tese) de que o homem é um ser racional e que, portanto, é capaz de tomar as decisões que melhor consultam seus reais interesses para, na sequência, se questionar (antítese) os fundamentos de tal pressuposição, indicando pesquisas que apontam para aspectos irracionais do comportamento humano, tentando-se, ao final (síntese), verificar como é possível a manutenção de tantos institutos jurídicos que pressupõe a racionalidade humana, com a tutela cada vez mais imprescindível de um ser humano que se revela cada vez mais vulnerável.

2 Trata-se da fala de Cássio, dirigida a Brutus, procurando convencê-lo a agir, para evitar que César se proclamasse Imperador e colocasse fim à República Romana. SHAKESPEARE, William. Júlio César. 2000. p. 18-19. Disponível em: < http://www.ebooksbrasil.org/eLibris/cesar.html>.

3 La rationalisation n'est pas un phénomène propre uniquement à l'epoque moderne, bien qu'il ait pris des proportions considérables depuis l'apparition des sciences expérimentales et mathématisables au lendemain immédiat de la Renaissance. La rationalité ne représent pas non plus un phénomène propre au droit, elle s'est développée dans l'ensemble des activités humaines. (Em tradução livre: A racionalização não é um fenômeno específico da era moderna, embora tenha tomado proporções consideráveis, desde o surgimento das ciências experimentais e matematizáveis subseqüentes ao Renascimento. A racionalidade não representa mais um fenômeno próprio do direito, pois tem se desenvolvido em todas as áreas humanas). CHARDIN, Nicole. Le contrat de consommation de crédit et l'autonomie de la volonté. Paris: LGDJ, 1988. p. 173. 
ter saído das cavernas e, aos poucos, se organizado, liberando tempo para reflexões além das necessidades imediatas de garantir a sobrevivência física, o bomo sapiens questionou-se sobre suas diferenças frente aos demais animais. A diferença mais evidente parecia ser a inteligência humana, vista como capacidade de refletir e tomar decisões, alterando o meio ambiente e nele introduzindo inovações ${ }^{4}$. Os demais animais eram vistos como seres vivos que apenas reproduziam padrões instintivos, meramente reagindo a estímulos externos, incapazes de terem ações proativas. Inteligência, portanto, seria o fator distintivo.

Todavia, muito tempo teve que passar para que o homem moderno percebesse que os animais, também, possuem inteligência, ainda que em níveis diversos e inferiores à dos humanos (ao menos na concepção vulgar de inteligência). Pensou-se, assim, que a afetividade pudesse ser o fator discriminatório ${ }^{5}$. Sob esse novo enfoque, seres humanos seriam a única espécie de animal capaz de estabelecer genuínas trocas afetivas, de amar e de sentir empatia (entendida como capacidade de mentalmente colocar-se no lugar de seu semelhante). Contudo, observações mais atentas do reino animal revelam que, também, os animais são capazes de estabelecer vínculos afetivos, tanto entre si como com seres humanos. Aliás, os vínculos afetivos que alguns seres humanos criam com seus animais domésticos, certamente, superam em intensidade os vínculos afetivos que certas pessoas nutrem para com outros seres humanos. Não por acaso surgiu, nas últimas décadas, um grande número de juristas envolvidos com a criação e desenvolvimento de um "direito dos animais". Correntes internas dividem-se entre ver nos animais objetos que não são coisas (posição adotada recentemente pela legislação portuguesa - Estatuto Jurídico dos Animais, entrado em vigor em $1^{\circ}$ de maio de 2017 —, reconhecendo-os como seres vivos dotados de sensibilidade, autonomizando-os face a pessoas e coisas), e, portanto, merecedores de especial proteção jurídica, até correntes que identificam os animais como sujeitos não humanos ${ }^{6}{ }^{7}$

Rousseau lançou, então, a ideia de que a diferença entre seres humanos e os demais animais residiria não na inteligência e nem na afetividade — comuns a humanos e a animais, embora em graus diversos — mas sim na perfectibilidade, ou seja, na capacidade exclusiva dos seres humanos de pensar no futuro, de projetar-se, de melhorar-se, de aperfeiçoar-se ou até mesmo de tomar decisões que o prejudicam e podem até ameaçar sua existência pessoal ${ }^{8}$. Os demais animais, ao contrário, seriam incapazes de refletir sobre o futuro, de per-

4 HARARI, Yuval Noah. Sapiens: uma breve história da humanidade. Tradução Janaína Marcoantonio. 19. ed. Porto Alegre: L\&PM, 2017.

5 A ideia foi avançada por René Descartes. Sobre sua contribuição sobre o tema, comparada com a distinção aristotélica (baseada na capacidade humana de raciocinar) que a precedeu e com a ideia rousseauniana de perfectibilidade (ligada à liberdade) que a sucedeu, v. FERRY, Luc. Aprender a viver: filosofia para os novos tempos. Tradução Véra Lucia dos Reis. Rio de Janeiro: Objetiva, 2006. Capítulo 2, especialmente o item denominado "Três consequências maiores da nova definição das diferenças entre animalidade e humanidade: os homens, únicos seres portadores de história, de igual dignidade e de inquietação moral”.

6 Não é recente o reconhecimento que os animais têm direito a proteção especial, diferenciando-se das coisas. Se alguém chuta seu balde e o destrói, tal atitude é irrelevante para o Direito. Todavia, não pode fazer o mesmo com um cachorro, mesmo que lhe pertença. Em 27/01/1978 a UNESCO/ONU aprovou a Declaração Universal dos Direitos dos Animais, cujo preâmbulo inicia com o "considerando" que todo o animal possui direitos. Seu artigo $1^{\circ}$ reza que "Todos os animais nascem iguais diante da vida e têm o mesmo direito à existência", e o art. $2^{\circ}$ estabelece que “a) Cada animal tem direito ao respeito; b) O homem, enquanto espécie animal, não pode atribuir-se o direito de exterminar os outros animais, ou explorá-los, violando esse direito. Ele tem o dever de colocar a sua consciência a serviço dos outros animais; c) Cada animal tem direito à consideração, à cura e à proteção do homem.” 7 Mais de um habeas-corpus já foi concedido a macacos, por exemplo. Notícia de O Globo, de 05/04/2017, por exemplo, noticia a concessão, na Argentina, de habeas corpus para que a chimpanzé Cecília fosse liberada de zoológico argentino, onde vivia há 19 anos, a fim de ser transferido a um santuário natural no Brasil - Santuário dos Grandes Primatas, de Sorocaba (https://oglobo.globo. $\mathrm{com} /$ sociedade/sustentabilidade/chimpanze-argentina-consegue-habeas-corpus-para-ir-para-santuario-brasileiro-21162673). Em 25 de abril de 2015, a justiça nova-iorquina concedeu liminar em habeas corpus a dois chimpanzés, Hercules e Leo, visando garantirlhes a libertação do laboratório da Universidade Stony Brook, onde viviam confinados. O habeas fora impetrado por advogados da ONG The Nonbuman Rights Project. A liminar foi revogada no dia seguinte, mas permitiu-se que o processo prosseguisse (https:// www.conjur.com.br/2015-abr-25/justica-eua-reconhece-status-pessoa-chimpanzes-dia). A Argentina tem sido pioneira quanto a esse aspecto, pois em 2014 a fêmea de orangotango Sandra já fora beneficiada por uma decisão judicial muito semelhante àquela que favoreceu Cecília, segundo notícia da Folha de São Paulo, edição digital (artigo de Reinaldo José Lopes, de 05/04/2017 - http:/ / www1.folha.uol.com.br/ambiente/2017/04/1873046-habeas-corpus-de-primata-e-fruto-de-decadas-de-articulacao-politica.shtml). 8 Rousseau assim expressa esse raciocínio: "Não vejo em todo animal senão uma máquina engenhosa, à qual a natureza deu sentidos para prover-se, ela mesma, e para se preservar, até certo ponto, de tudo o que tende a destruí-la ou perturbá-la. Percebo precisa- 
der-se em devaneios sobre o que serão num tempo, o futuro, processo reflexivo, esse, que é inerente apenas ao ser humano. Filhotes e jovens animais não ficam angustiados sobre o que os espera no futuro. Apenas reagem ao presente, agindo instintivamente, reproduzindo padrões de comportamento de sua espécie. Se escassear a caça em seu território, um leão — embora rei dos animais - morrerá de fome, mas não pensará em tornar-se herbívoro ou de comer frutos ou tubérculos que estejam disponíveis. Iguanas, golfinhos e gaviões provavelmente adotam os mesmos comportamentos que seus ancestrais há mil anos. Daqui a mil anos, seus descendentes (se os 'superiores' seres humanos permitirem sua sobrevivência) provavelmente repetirão os mesmos padrões de comportamento. O mesmo não ocorre com os seres humanos, que procuram se 'reinventar', mudando comportamentos, formas de convivência, formas de produção, profissões, alteram valores, modificam formas de convivência social e política, transformam arranjos familiares etc.

Outra forma de expressar a perfectibilidade rousseauniana é por meio da concepção do ser humano como ser-liberdade, sendo a liberdade a verdadeira característica humana. O ser humano é o único ser vivo que tem capacidade de projetar e projetar-se. Seus atos, como dito, diferentemente dos atos dos animais, não são reações, mas sim implementação de projetos.

A liberdade faz da pessoa um ser projetivo, criativo, responsável, dinâmico, em contínuo movimento, moldando sua personalidade por meio do tempo. Essa liberdade pode ser vista como ontológica (existente no mundo interior - portanto, ilimitada e absoluta) e como fenomênica (ocorrente no mundo exterior - e, portanto, limitada, relativa e condicionada tanto por fatores do mundo exterior quanto do mundo interior). ${ }^{9}$

A primeira, por ser absoluta e ilimitada, é irrelevante para o Direito. Este se interessa pela segunda, ou seja, pelo projeto de vida que se efetiva por meio de atos ou condutas, já que o Direito somente se preocupa com condutas humanas intersubjetivadas.

A liberdade se fenomenaliza (a raiz grega da palavra fenômeno significa "o que se mostra", "o que aparece no mundo") por meio de atos, condutas, comportamentos do ser humano, sendo dessa exteriorização que se ocupa o Direito.

De certa forma, essa liberdade, que caracterizaria o ser humano, representa aquilo que a pessoa decide ser e fazer "em" sua vida e "com" sua vida. Trata-se do "dasein" (o 'ser aí") heideggeriano, que compreende o ser humano como um "ser projetante". Ou, segundo Jaspers, o projeto de vida do homem permite a ele "chegar a ser o que pode e quer ser".

Tanto no campo da moral como no da religião, bem como na filosofia e no Direito, essas ideias desembocaram na conhecida concepção de "livre-arbítrio", isto é, a liberdade de agir conforme nossa vontade, com a resultante responsabilidade pelos efeitos de nossas escolhas.

Desde Aristóteles a noção de autodeterminação é a base da convivência humana, pois partimos dessa liberdade para recompensar e responsabilizar pessoas em virtude de suas atitudes livremente tomadas.

Para justificar a importância central do homem, $\operatorname{Kant}^{10}$ criou a ideia de dignidade da pessoa humana que o diferenciaria dos demais entes naturais. Afirmava ele que o animal está submetido às leis naturais e necessárias de causa e efeito, porque reagiam, unicamente, por instinto, enquanto o homem pode ultrapassar sua

mente as mesmas coisas na máquina humana, com a diferença de que só a natureza faz tudo nas operações do animal, ao passo que o homem concorre para as suas na qualidade de agente livre. Um escolhe ou rejeita por instinto, o outro por um ato de liberdade, o que faz com que o animal não possa afastar-se da regra que lhe é prescrita, mesmo quando lhe fosse vantajoso fazê-lo, e que o homem dela se afaste frequentemente em seu prejuízo." ROUSSEAU, Jean-Jacques. Discurso sobre a origem da desigualdade. Tradução Maria Lacerda de Moura. Ed. Ridendo castigat mores, 2001. p. 54 e 55. Sobre o impacto dessas ideias, v. a obra de Luc Ferry, já referida, bem como COMTE-SPONVILLE, André. Dicionário filosófico. Tradução Eduardo Brandão. São Paulo: Martins Fontes, 2003.

9 A respeito dessas esferas da liberdade e do profundo significado da liberdade humana enquanto signo distintivo dos demais animais consulte-se SESSAREGO, Carlos Fernández. Trascendencia y reparación del "daño al proyecto de vida" en el umbral del siglo XXI. In: HERNÁNDEZ, Carlos Arturo et al (Org.). La Responsabilidad Civil. Bogotá: Universidad Libre, 2014. (Tendencias Contemporáneas del Derecho, v.19). p. 355.

10 KANT, Immanuel. Crítica da razão pura. Tradução Lucimar A. Coghi Anselmi, Fulvio Lubisco. 3. ed. São Paulo: Ícone, 2011. 
condição natural ascendendo a uma "segunda natureza". ${ }^{11}$ Assim, o ser humano poderia, por seu intelecto, superar a natureza. Essa superioridade humana que torna os homens capazes de livremente controlar e modificar a própria natureza conferiria dignidade ao homem.

O conhecimento de algumas reações naturais — transmitido pela linguagem ${ }^{12}$ de geração a geração — fez evoluir nosso intelecto, permitindo-nos fazer determinadas previsões. Usamos a razão para, com base na memória, analisar os dados colhidos pelos sentidos e buscar uma explicação para as causas, conforme já alertava o Princípio da Razão Suficiente de Leibniz, o qual afirmava ser este um comportamento inerente à racionalidade humana. ${ }^{13}$

Embora alguns filósofos tenham apresentado boas reflexões questionando a premissa da autodeterminação - como Spinoza ${ }^{14}$, Schoppenhauer ${ }^{15}$, Nietzsche ${ }^{16}$ e mais recentemente Deleuze ${ }^{17}$ 一, o fato é que esta sempre prevaleceu e sempre contou com muitos adeptos, tal como Sartre e seu existencialismo: "O homem está condenado a ser livre.”18

Essas ideias, que surgiram, inicialmente, no campo da religião e da filosofia, posteriormente, migraram para o Direito que, como foi dito acima, funda boa parte de seus institutos na equação liberdade-responsabilidade. Ainda que se trate de noção essencial para a operacionalidade de tais institutos, a noção de racionalidade e livre-arbítrio vem sendo cada vez mais questionada. É o que se passa a analisar.

\section{A racionalidade Questionada}

Nossa capacidade de compreender e prever o futuro realmente é muito superior à dos outros animais. Mas será tão desenvolvida quanto imaginamos?

Ao menos desde Kant a racionalidade das escolhas humanas tem sido contestada ${ }^{19}$, em razão da percepção do peso dos mais variados fatores capazes de influenciar o processo de tomada de decisão.

Sem dúvida o ser humano é o animal mais bem sucedido em sua capacidade de adaptar o meio às suas necessidades, em vez de se adaptar ao meio, como ocorre com as demais espécies, segundo o darwiniano princípio da evolução biológica. ${ }^{20} \mathrm{Faz}$ isso movido por sua vontade. Essa vontade, na esteira do pensamento de Arthur Schopenhauer, antecede até mesmo a cognição: "este intelecto é o secundário, o posterius do organismo e, enquanto mera função cerebral, condicionado por este. A vontade, por outro lado, é primária, é o prius do organismo, sendo este condicionado por ela." ${ }^{21}$

Também Nietzsche critica o apego fanático à lógica racional: “a 'razão’ é a causa de falsificarmos o tes-

11 RABENHORST, Eduardo Ramalho. O valor da pessoa humana e o valor da natureza. In: MELGARÉ, Plínio; ALMEIDA FILHO, Agassiz. (Org.). Dignidade da pessoa humana: fundamentos e critérios interpretativos. São Paulo: Malheiros, 2010. p. 30.

12 WITTGENSTEIN, Ludwig. Investigações filosóficas. Tradução Marcos G. Montagnoli e Emmanuel Carneiro Leão. 9. ed. Petrópolis: Vozes; Bragança Paulista: Editora Universitária São Francisco, 2014.

13 KANT, Immanuel. Crítica da razão pura. Tradução Lucimar A. Coghi Anselmi, Fulvio Lubisco. 3. ed. São Paulo: Ícone, 2011. p. 190-194.

14 SPINOZA, Benedictus de. Ética. Tradução Thomaz Tadeu. 2. ed. Belo Horizonte: Autêntica, 2013. p. 36.

15 SCHOPENHAUER, Arthur. O mundo como vontade e representação. São Paulo: Saraiva, 2001. SCHOPENHAUER, Arthur. Sobre a vontade na natureza. Tradução Gabriel V. Silva. Porto Alegre: L\&PM, 2013.

16 NIETZSCHE, Friederich. Assim falou Zaratustra. Tradução Carlos Duarte e Anna Duarte. São Paulo: Martin Claret, 2012. NIETZSCHE, Friederich. Crepúsculo dos ídolos. Tradução Paulo César de Souza. São Paulo: Companhia das letras, 2006.

17 DELEUZE, Gilles. Diferença e repetição. Tradução Luiz Orlandi e Roberto Machado. Lisboa: Relógio d'Água, 2000.

18 SARTRE, Jean-Paul. O existencialismo é um bumanismo. Tradução João Batista Kreuch. 3. ed. Petrópolis: Vozes, 2014. p. 24.

19 KANT, Immanuel. Crítica da razão pura. Tradução Lucimar A. Coghi Anselmi, Fulvio Lubisco. 3. ed. São Paulo: Ícone, 2011. p. 211-214.

20 DARWIN, Charles. A origem das espécies por meio da seleção natural. Tradução André Campos Mesquita. São Paulo: Escala, 2009.

21 SCHOPENHAUER, Arthur. Sobre a vontade na natureza. Tradução Gabriel V. Silva. Porto Alegre: L\&PM, 2013. p. 66. 
temunho dos sentidos. [...] Nós possuímos ciência, hoje, exatamente na medida em que resolvemos aceitar o testemunho dos sentidos"22.

Com base no que sentimos, estabelecemos uma lógica relacionada àquilo que a memória apresenta como causas e consequências. A partir desse mecanismo, reproduzimos atitudes que reconhecemos nos outros indivíduos. Por isso um bebê tenta bater palmas ao ver um adulto fazendo o mesmo. Nesse diapasão, o ser humano define quem ele é, imitando características que ele deseja possuir e aperfeiçoando-as à sua maneira (adequando-as). Não apenas seres humanos fazem isso, diria Pavlov. Em animais não humanos, porém, chamamos isso de instinto.

A propósito, é explorando essa característica humana que os publicitários promovem um produto associando-o a um personagem famoso, ressaltando que "fulano" possui aquele produto e, por isso, "você" também deve desejá-lo. "A necessidade de imitação que o consumidor sente é esse desejo infantil, que por vezes racionalizamos com afirmações do estilo "eu mereço". Num nível patológico, consumimos para evitar "o sentimento torturante de estar à margem da existência." 23 O chamado "consumo conspícuo" 24 demonstra que o comportamento humano atende mais a estímulos externos do que a uma vontade independente. ${ }^{25}$

Exemplo disso são os indivíduos absolutamente racionais que, no entanto, gastam fortunas em um produto. Pagam pelo símbolo ${ }^{26}$ que o produto representa naquela sociedade, ${ }^{27}$ agindo tal qual o bebê que reconhece determinado símbolo e o repete. Não chega a ser um comportamento irracional, pois tem uma lógica e um propósito: ser identificado por aqueles que comungam dos mesmos valores. ${ }^{28}$ Todavia, tampouco tal comportamento pode ser tido como realmente livre e autônomo.

22 NIETZSCHE, Friederich. Crepúsculo dos ídolos. Tradução Paulo César de Souza. São Paulo: Companhia das letras, 2006. p. 26.

23 DEBORD, Guy. A sociedade do espetáculo. Tradução Estela dos Santos Abreu. Rio de Janeiro: Contraponto, 1997. p. 140-141.

24 VEBLEN, Thorstein B. A teoria da classe ociosa: um estudo econômico das instituições. São Paulo: Pioneira, 1965.

25 Para um aprofundamento do tema, remete-se ao capítulo "Racionalidade humana", da obra de SCHMIDT NETO, André Perin. Contratos na sociedade de consumo: vontade e confiança. São Paulo: Revista dos Tribunais, 2016. p.123/156.

26 O vocábulo "símbolo" tem sua origem etimológica nas expressões gregas sym (juntar, unir) e balein (em direção a um objetivo, uma meta). Na Grécia antiga, representava o ato de unir dois pedaços de uma moeda partida quando da separação de duas pessoas. Assim, quando uma delas pretendia mandar uma mensagem para a outra, remetia sua metade pelo mensageiro para que o remetente confirmasse a autoria do recado juntando as duas metades da moeda. Desse modo, em termos psicanalíticos, a palavra passou a significar a união de algo conhecido (consciente) a algo desconhecido (inconsciente). "Assim, o símbolo sempre contém um aspecto irracional e tem um enorme poder de mobilização. Podemos perceber o símbolo em formas concretas, como bandeiras, slogans e hinos (...)" - RAMOS, Denise Gimenez; MACHADO JUNIOR, Pericles Pinheiro. Individuação e subjetivação: os conceitos junguianos de inconsciente coletivo e arquétipo mostram o caráter universal das imagens e dinâmicas do inconsciente que representam modos de estruturação da subjetividade no processo de individuação. In: PINTO, Manuel da Costa (Org.). O livro de ouro da psicanálise: o pensamento de Freud, Jung, Melanie Kein, Lacan, Winnicott e outros. 2. ed. Rio de Janeiro: Ediouro, 2007. p. 185. Isso se aplica ao objeto do consumo que, nesta sociedade de consumidores representa, mais do que sua utilidade, a identidade de quem o adquire. 27 LLOSA, Mario Vargas. A civilização do espetáculo: uma radiografia do nosso tempo e da nossa cultura. Tradução Ivone Benedetti. Rio de Janeiro: Objetiva, 2013. p. 20.

28 “'Minha mãe é professora de uma escola primária', disse Corinne a uma entrevistadora, 'e quando ela pergunta aos meninos o que eles querem ser quando crescer, eles respondem: 'Não sei, só quero ser famoso'.' Nesses sonhos 'ser famoso' não significa nada mais (mas também nada menos!) do que aparecer nas primeiras páginas de milhares de revistas e em milhões de telas, ser visto, notado, comentado e, portanto, presumivelmente desejado por muitos — assim como sapatos, saias ou acessórios exibidos nas revistas luxuosas e nas telas de TV, e por isso vistos, notados, comentados, desejados... 'Há mais coisas na vida além da mídia', observa Germaine Greer, 'mas não muito... Na era da informação, a invisibilidade é equivalente à morte.” BAUMAN, Zygmunt. Vida para o consumo: a transformação das pessoas em mercadorias. Tradução Carlos Alberto Medeiros. Rio de Janeiro: Zahar, 2008. p. 21. Experimentos demonstram que a maioria das pessoas das classes mais abastadas raramente dirigem o olhar para pessoas que ocupam papéis sociais tidos como subalternos, como faxineiros, encarregados de limpeza, garis, mendigos, etc, criando nesses uma exasperante 'síndrome da invisibilidade'. Para alguns estudiosos da criminalidade, esse sentimento por vezes está na origem inconsciente de alguns tipos de crime, como o assalto à mão armada: quando o criminoso aponta a arma para a cabeça de sua vítima, não há como esta não reconhecer a existência e toda a visibilidade do ser "que está" assaltante. Esse termo ganhou notoriedade com o experimento feito por Fernando Braga da Costa, ao elaborar sua pesquisa de graduação na USP, em psicologia social, ocasião em que se vestiu de gari no campus universitário e foi trabalhar com os mesmos. Vestido de gari, percebeu que jamais era reconhecido por seus colegas e professores - porque jamais dirigiam o olhar para ele, embora cruzando pelos mesmos espaços -, embora rapidamente identificado pelas mesmas pessoas quando trajado "normalmente". Seu impressionante experimento foi posteriormente convertido em livro - COSTA, Fernando Braga da. Homens invisiveis: relatos de uma humilhação social. São Paulo: Globo, 2004. 
A racionalidade do agir humano, já questionada filosoficamente, passou, também, a sofrer intensos e consistentes ataques provenientes de outras áreas científicas, como a psicologia, tema do próximo item.

\section{A RACIONALIDADE, SEGUNDO A PSICOLOGIA COMPORTAMENTAL}

O estudo do comportamento humano e seu condicionamento ganhou impulso com a psicologia comportamental e ciências afins, que cresceram muito, após o surgimento das ideias de condicionamento decorrentes das experiências com cães, realizadas por Ivan Pavlov.

Em conhecido experimento, ao estudar a produção de saliva em cachorros expostos a diferentes alimentos, o filósofo soviético percebeu que, com o tempo, não mais apenas apresentação da comida aos cães lhes causava salivação, mas também o som dos passos dos funcionários que se dirigiam ao canil para alimentá-los. Passou, então, a alimentar os cães sempre ao som de uma determinada campainha, e após repetidas vezes, a salivação, que seria uma reação que deveria ocorrer, apenas, quando o alimento era colocado em sua boca para facilitar a digestão, passou a ocorrer com o simples som daquela mesma campainha. Assim, os animais ofereciam respostas comportamentais ao meio, como reflexos incondicionados, fruto da repetição (experiências resgatadas pela memória), sendo possível criar ou remover respostas fisiológicas e psicológicas em animais e, extensivamente, também em seres humanos.

Na construção do Behaviorismo, Thorndike trouxe contribuições importantes em seus estudos com gatos. Descreveu o comportamento dos felinos submetidos a testes em jaulas denominadas "caixas-de-problemas". "As portas de alguma destas caixas só podiam ser abertas puxando-se um cordão ou um nó, que estavam no interior, ou mediante pressão sobre uma alavanca. $\mathrm{O}$ animal em experiência, habitualmente faminto, tinha de libertar-se da prisão em que fora colocado." ${ }^{29}$ Depois de submetidas várias vezes ao mesmo teste, as cobaias passavam a demonstrar mais eficiência para a solução do problema, demonstrando a aprendizagem por experiência dos animais. "Pouco a pouco, de uma a outra experiência, tornavam-se cada vez mais objetivados os movimentos do animal: todos os movimentos desnecessários são refreados. Sobra apenas um grupo de movimentos que conduzem ao êxito." ${ }^{30}$

As experiências com animais foram superadas pelo behaviorismo, que se distinguiu por estudar o que se passava na mente dos testados e não apenas seus movimentos e reações externamente visíveis. O behaviorismo proposto por John Broadus Watson, em 1913, com a publicação do artigo "Psychology as the Behaviorist Views It", e que depois ganhou diversos desdobramentos, passou a afirmar que o ser humano aprende, essencialmente, por meio da imitação, da observação e da reprodução dos comportamentos dos outros, e que nossas ações são meras respostas ao ambiente externo. Críticas como as da psicologia da Gestalt — que acusaram o behaviorismo de estudar comportamentos isolados ignorando o todo — têm transformado esses estudos. ${ }^{31}$

As pesquisas mais atuais confirmam as limitações à racionalidade pura. Hoje a psicologia cognitiva busca responder como o homem compreende o mundo e de que modo reage a ele, buscando adaptá-lo a si e às suas necessidades. Conforme a psicologia, somos o reflexo de nossas experiências, notadamente as vividas durante nosso período de formação. Assim, uma ação realizada na infância pode provocar uma reação (personalidade) na vida adulta, levando-nos a ter determinado comportamento, comprometendo sua racionalidade.

29 PUCHKIN, V. N. Heurística: a ciência do pensamento criador. Tradução Vera Neverova. Rio de Janeiro: Zahar Editores, 1969. p. 25.

30 PUCHKIN, V. N. Heurística: a ciência do pensamento criador. Tradução Vera Neverova. Rio de Janeiro: Zahar Editores, 1969. p. 25.

31 STARnBERG, Robert J. Psicologia cognitiva. Tradução Anna Maria Dalle Luche e Roberto Galman. São Paulo: Cangage Learning, 2010. p. 8-9. 
Por outro lado, temos a tendência de avaliar comportamentos alheios com base em nossos próprios estados mentais. Essa tendência foi comprovada por uma pesquisa que consistiu em solicitar a pessoas que assistissem um filme no qual formas simples, como triângulos e quadrados, moviam-se aleatoriamente na tela. Quando perguntados sobre o que haviam visto, a maioria das pessoas atribuiu motivos e intenções às formas inanimadas, comportamento que demonstra a tendência natural das pessoas em tentar explicar o comportamento alheio com base em estados mentais e desejos próprios, comprovando que tais explicações não são necessariamente precisas. É quase inevitável não ligar experiências sensoriais a estados mentais ${ }^{32}$, ignorando, também, que decisões e julgamentos são influenciados por fatores sociais e culturais. ${ }^{33}$

Na sociedade de consumo, o conhecimento dos mecanismos por meio dos quais tomamos decisões serve, também, à manipulação do comportamento alheio, na busca de resultados econômicos. Esses aportes da psicologia cognitiva "ingressaram na Ciência Econômica, gerando um sub-ramo denominado de Economia Comportamental” ${ }^{34}$, tema do próximo item.

\section{A RACIONALIDADE, SEgundo a ECONOMIA COMPORTAMENTAL}

De algumas décadas para cá, um ramo da economia, denominada de economia comportamental, vem chamando atenção por mostrar como o ser humano é influenciável e principalmente pelas aplicações práticas que tal conhecimento permite. Seu foco principal recai sobre os limites da racionalidade dos agentes econômicos. Tal ramo do saber incorpora insights da psicologia, neurociência e Teoria Microeconômica.

Essa nova ciência possibilita visões esclarecedoras e desmistificadoras. Estudos nessa área tendem a crescer e a chamar cada vez mais a atenção, pois já haviam rendido dois prêmios Nobel, para Herbert Simon, em 1978 e Daniel Kahneman ${ }^{35}$, em 2002. Em 2017 o economista Richard Thaler igualmente recebeu o Prêmio Nobel de Ciências Econômicas exatamente pelas suas contribuições à economia comportamental e por, pioneiramente, ter descrito como as pessoas são previsivelmente irracionais em suas condutas ${ }^{36}$, principalmente econômicas. Tais achados interessam ao mercado, sempre ávido de informações que possam ser utilizadas

32 O experimento foi extraído de COMMONS, Michael Lamport; MILLER, Patrice Marie. Folk psychology and the law: why behavioral science needs to replace folk psychology. Revista Brasileira de Estudos Políticos, Belo Horizonte, n. 96, p. 10, jul./dez. 2007. Referidos autores mencionam que a noção de livre-arbítrio consiste na crença de que somos absolutamente independentes, sendo que tal noção decorre da filosofia, da religião e do direito ocidentais- op. cit., p. 12.

33 Percepção essa que não é nada recente, já que Descartes há cerca de quatro séculos já havia advertido que "[...] tendo reconhecido que os que têm sentimentos muito contrários aos nossos nem por isso são bárbaros nem selvagens, mas que muitos usam, tanto ou mais do que nós, a razão; e tendo considerado o quanto um mesmo homem, com seu mesmo espírito, criado desde a infância entre franceses ou alemães, torna-se diferente do que seria se tivesse vivido sempre entre chineses ou canibais, e de que maneira, até nas modas de nossas roupas, a mesma coisa que nos agradou dez anos atrás, e que nos agradará talvez daqui dez anos, nos parece agora extravagante ou ridícula: de modo que é bem mais o costume e o exemplo que nos persuadem do que qualquer conhecimento certo, e que, no entanto, a pluralidade das vozes não é uma prova que valha para as verdades um pouco difíceis de descobrir, porque é bem mais provável que um homem sozinho as encontre do que um povo inteiro; [...]" DESCARTES, René. Discurso do método. Tradução Paulo Neves. Porto Alegre: L\&PM, 2013. p. 47-48.

34 OLSSON, Gustavo André. Análise econômica do direito penal e teoria sistêmica. Curitiba: Juruá, 2014. p. 168.

35 Em livro mais recente, Thinking, Fast and Slow ("Pensando, rápido e devagar", publicado em português pela Editora Objetiva, em 2012), Daniel Kahneman, defende a tese de que grande parte das nossas decisões são puramente emocionais, mesmo quando acreditamos que estamos tomando decisões racionais, baseadas em dados concretos. Isso explica, por exemplo, por que as pessoas criam empatia por um político apenas pela sua fisionomia (é um fato que candidatos ou candidatas bonitos/as tendem a ganhar um número razoável de votos apenas pela sua beleza, independentemente de suas qualidades políticas, apesar dessas serem, obviamente, o único fator relevante para a ocupação de um cargo público), ou porque professores tendem a dar melhores notas a alunos que já se destacam (apesar da intuitiva percepção de que nem sempre um bom aluno tem necessariamente elevado desempenho em todas as tarefas e avaliações a que se submete).

36 "People respond to incentives, although not necessarily in ways that are predictable or manifest. Therefore, one of the most powerful laws in the universe is the law of unintended consequences" (em tradução livre: pessoas respondem a incentivos, embora não necessariamente de forma previsível ou manifesta. Portanto, uma das mais poderosas leis no universo é a lei das consequências não intencionais) - LEVITT, Steven D.; DUBNER, Stephen J. Super Freakonomics. New York: HarperCollins Publishers, 2009 . p.14. 
para aumentar a venda de seus produtos. Quanto mais supérfluos forem os produtos e serviços que se queiram lançar no mercado, maior é a habilidade necessária para vendê-los ao público. Qualquer informação útil para aumentar as chances de colocação de produtos ou serviços no mercado, é sempre muito bem-vinda.

Sobre seus achados, diz-se que:

Agregando elementos de Psicologia, a Economia comportamental busca descrever um ser humano mais real e concreto e, o que é o principal, o seu comportamento econômico. Considerando que as decisões humanas são sempre econômicas (no sentido de que o ser humano faz sempre ponderações de custo-benefício em seu processo de tomada de decisão), a Economia Comportamental (EC) parte do pressuposto de que as decisões humanas são sempre racionais, embora seja limitada tal racionalidade.

A EC descreve a dificuldade humana com a tomada de decisões intertemporais, assim definidas aquelas para as quais se faz um pequeno sacrifício hoje, à espera de um benefício maior no futuro. Descreve, igualmente, o chamado superotimismo humano, ou a crença dos indivíduos de que eles são mais propensos ao acontecimento de boas coisas em suas vidas que nas dos outros. Comprova, empiricamente, a afirmação de que, por vezes, as escolhas dos seres humanos baseiam-se em compulsões, ódio, paixões, vícios e não representam, exatamente, uma expressão de escolha livre. Confirmam o caráter limitado da força de vontade humana. Demonstram que os seres humanos costumam selecionar, em ter as opções possíveis, os argumentos que confirmam aquilo que eles previamente desejavam como conclusão. ${ }^{37}$

Alguns temas são recorrentes nos estudos da economia comportamental, como a heurística, segundo a qual seres humanos tomam a esmagadora maioria de suas decisões usando atalhos mentais, ou, então, fazendo uso de estereótipos que representam verdadeiros paradigmas emocionais mentais, servindo de filtros para a compreensão da realidade e moldando nossas reações aos eventos a que somos expostos. Outro tema privilegiado de estudo são as ineficiências do mercado, em razão de tomadas de decisão não racionais. Voltaremos a alguns desses aspectos no próximo item.

Com o provocante título "O livre-arbítrio não existe, dizem neurocientistas", a revista Veja $a^{38}$ publicou reportagem cujo subtítulo afirma que "Novas pesquisas sugerem que o que cremos ser escolhas conscientes são decisões automáticas tomadas pelo cérebro. $\mathrm{O}$ homem não seria, assim, mais do que um computador de carne".

No texto, afirma-se que "o exército dos deterministas ganhou um reforço de peso: o dos neurocientistas." Segundo estes, o livre-arbítrio não é mais que uma ilusão, conclusão a que chegam com base em um vasto arsenal de dados, colhidos por meio de testes que monitoram o funcionamento do cérebro:

Mais rápido que o pensamento - Experimentos que vêm sendo realizados por cientistas há anos conseguiram mapear a existência de atividade cerebral antes que a pessoa tivesse consciência do que iria fazer. Ou seja, o cérebro já sabia o que seria feito, mas a pessoa ainda não. Seríamos como computadores de carne - e nossa consciência, não mais do que a tela do monitor. Um dos primeiros trabalhos que ajudaram a colocar o livre-arbítrio em suspensão foi realizado em 2008. O psicólogo Benjamin Libet, em um experimento hoje considerado clássico, mostrou que uma região do cérebro envolvida em coordenar a atividade motora apresentava atividade elétrica uma fração de segundos antes dos voluntários tomarem uma decisão — no caso, apertar um botão. Estudos posteriores corroboraram a tese de Libet, de que a

37 OLIVEIRA, Amanda Flávio de; MOURA, Walter José Faiad de. É preciso proteger o fumante de si mesmo?. Revista Científica Virtual da Escola Superior da Advocacia da OAB-SP, n. 17, inverno 2014. Edição especial: Direito e Tabaco. São Paulo: OAB/SP, 2014. p. 162/163. Dentro da mesma linha, refere Isabella Henriques que o mote da sociedade de consumo é o pensar no momento atual, no prazer imediato, pois é uma sociedade que prima pelo imediatismo, sem lembrar o passado ou preocupar-se com o futuro. E prossegue: "A ideia é curta agora tudo o que é possível, pois você é merecedor desse prazer. Essa ideia é muito eficaz porquanto o ser humano reconhece a sua condição de mortalidade. Por isso mensagens que induzem a esse prazer imediato são facilmente absorvidas, ainda que no caso de promoção de produtos notoriamente conhecidos por seus potenciais danos à saúde, inclusive com risco de morte, como são o tabaco e o álcool. A ideia aqui é: se eu vou morrer mesmo, que ao menos seja desfrutando algo que acredito me dê prazer e me faça feliz" - HENRIQUES, Isabella. "Controle do Tabaco X Controle do Álcool: Convergências e Diferenciações Necessárias. In: HENRIQUES, Isabella. Controle do tabaco x controle do álcool: convergências e diferenciações necessárias. In: HOMSI, Clarissa Menezes (Coord.). Controle do tabaco e o ordenamento jurídico brasileiro. Rio de Janeiro: Lúmen Juris, 2011. p. 249.

38 Artigo escrito por Aretha Yarak, publicado em 06/05/2016, disponível em https://veja.abril.com.br/ciencia/o-livre-arbitrionao-existe-dizem-neurocientistas/ acesso em 25/05.2018. 
atividade cerebral precede e determina uma escolha consciente.

Um deles foi publicado no periódico científico PLoS ONE, em junho de 2011, com resultados impactantes. O pesquisador Stefan Bode e sua equipe realizaram exames de ressonância magnética em 12 voluntários, todos entre 22 e 29 anos de idade. Assim como o experimento de Libet, a tarefa era apertar um botão, com a mão direita ou a esquerda. Resultado: os pesquisadores conseguiram prever qual seria a decisão tomada pelos voluntários sete segundos antes deles tomarem consciência do que faziam.

No mesmo texto, refere-se que, para a neurociência, a mente é um produto do cérebro. Ou seja, como o cérebro já decidiu o que fazer, é preciso explicar a decisão. "É aí que entra a nossa consciência. Ela também é um produto da atividade cerebral, que surge para dar coerência às nossas ações no mundo. O cérebro toma a decisão por conta própria e ainda convence seu 'dono' que o responsável foi ele.”

Tal como os indivíduos, as massas (grupos de seres) têm suas reações próprias, ainda menos comprometidas com a razão, comportando-se como rebanho ${ }^{39}$.

A respeito de nossa capacidade de, às vezes, ingenuamente agir como membros de rebanho, não é nova a sua constatação, como se percebe da leitura de texto originariamente escrito há quase cem anos:

O espírito da época, tal como se nos revela, é, muito frequentemente, apenas o espírito do grupo em que os acidentes do nascimento, da educação, da ocupação ou da companhia nos colocaram. Nenhum esforço ou revolução do espírito removerá totalmente e para sempre o império dessas fidelidades subconscientes. 'As nossas crenças e opiniões', diz James Harvey Robinson ("The Still Small Voice of the Herd", 32 Political Science Quarterly 315), 'assim como os nossos padrões de procedimento, vem-nos insensivelmente como produto da nossa convivência com outros homens, não como resultado da nossa experiência pessoal e das inferências que nós próprios tiramos, individualmente, das nossas próprias observações. Somos constantemente mal induzidos pela nossa extraordinária faculdade de racionalização - isto é, de imaginar argumentos plausíveis para aceitar aquilo que nos é imposto pelas tradições do grupo a que pertencemos. Somos abjetamente crédulos por natureza e aceitamos instintivamente as sentenças do grupo. [....]; estamos sempre de novo ouvindo a vozinha tranquila do rebanho e prontos a defender e justificar suas instruções e conselhos, aceitando-os como maduros resultados do nosso próprio raciocínio ${ }^{40}$.

E esse comportamento de massas promove decisões da maioria que têm grande relevância para as nações. Esses mesmos seres manipuláveis decidem conjuntamente, desde a moda até os governantes. Não se descarta a presença de alguma racionalidade nesse processo de tomada de decisões. A questão consiste em saber o quanto ela é limitada diante das forças naturais, considerando-se que somos parte dessa natureza e algumas de nossas atitudes correspondem mais a reações a determinadas substâncias que compõem nosso corpo (e cérebro) e a nossas experiências, do que fruto amadurecido de nossas reflexões racionais e conscientes.

Essa noção de que o ser humano controla suas atitudes é tão forte que o próprio indivíduo que se comporta movido pelo inconsciente, quando perguntado, pode acreditar que, efetivamente, quis algo. Não temos plena consciência de que reagimos ao nosso inconsciente.

O Direito deve reconhecer que a vontade, enquanto tentativa de mudar o futuro pela tomada de decisões, não pode ser tida como o único fator a ser considerado, porque, em certas situações, ela pode ter sido induzida por quem detém o conhecimento de ciências que analisam padrões comportamentais.

O modelo econômico clássico baseia-se na ideia singela de que é da natureza humana tomar decisões

39 Bauman comenta essa transição afirmando que a sociedade líquido-moderna de consumidores tende a substituir o grupo (coordenado, onde cada membro assume uma função) pelo enxame (aglomerado de indivíduos que apenas segue a maioria) - BAUMAN, Zygmunt. Vida para o consumo: a transformação das pessoas em mercadorias. Tradução Carlos Alberto Medeiros. Rio de Janeiro: Zahar, 2008. p. 99-101.

40 CARDOZO, Benjamin Nathan. The nature of the judicial process. In: A NATUREZA do processo e a evolução do Direito. Revista AJURIS, p. 156, 1978. 
certas para nós mesmos. O exemplo clássico é comparar quem compra uma gravata para dar de presente a alguém - corre o risco dessa pessoa não estar necessitando de gravatas, ou não gostar da cor ou da estampa - e de alguém que vai comprar uma gravata para si - certamente só comprará se estiver necessitado e escolherá cores e estampas de sua predileção. Todavia, amplas pesquisas têm demonstrado a influência de diversos fatores irracionais que nos afetam a cada decisão, desde o subconsciente até fatores externos que nos induzem a não seguir a plena racionalidade. ${ }^{41}$ Como bem demonstra Dan Ariely, "nossos comportamentos irracionais não são aleatórios nem destituídos de sentido. São sistemáticos e, já que o repetimos incessantemente, previsíveis." ${ }^{42}$ Os novos estudos econômicos já passaram a levar em conta tais fatores comportamentais.

Enquanto os estudos jurídicos comumente partem da ideia de que é papel do Direito a análise sob a perspectiva do "mundo do dever ser", pautando o que é certo e errado, a Economia é capaz de abstrair as implicações da moral, atendo-se ao "mundo do ser". Como já foi dito, "o moralismo representa a forma como as pessoas gostariam que o mundo funcionasse, enquanto a economia representa a forma como ele realmente funciona." ${ }^{43}$

O Direito deve regular a Economia e, para isso, deve partir da premissa de que nem sempre os consumidores são plenamente racionais em suas escolhas.

Modern legal scholars frequently and increasingly base their analyses not on neoclassical economics' assumption of rationality, but on the assumption that individuals are subject to a number of systematic behavioral biases. This assumption is itself grounded largely in a substantial experimental literature documenting bounded rationality, errors in judgment, and non-standard preferences. ${ }^{44}$

Um dos autores a fazer tal análise é Cass R. Sunstein ${ }^{45}$, que baseia sua coletânea de artigos na ideia da "bounded rationality", inicialmente introduzida por Herber Simon, que nada mais é do que a noção de que "human cognitive abilities are not infinite", limitação que decorre do fato de que "we have limited computational skills and seriously flawed memories". ${ }^{6}$

Para lidar com tais limitações biológicas, bem como com as de tempo, adotamos atalhos mentais e regras de decisão que permitem que façamos escolhas. ${ }^{47}$ Mesmo com esses recursos, e muitas vezes por causa deles,

41 "Concluo, portanto, que a lógica deve ser ministrada nas escolas com o propósito de ensinar as pessoas a não raciocinar. Porque, se raciocinarem, certamente o farão de forma equivocada.” RUSSELL, Bertrand. Ensaios céticos. Tradução Marisa Motta. Porto Alegre: L\&PM Editores, 2014. p. 93.

42 ARIELY, Dan. Previsivelmente irracional: como as situações do dia-a-dia influenciam as nossas decisões. Tradução Jussara Simões. Rio de Janeiro: Elsevier, 2008. p. 7.

43 LEVITT, Steven. D.; DUBNER, Stephen J. Freakonomics: o lado oculto de tudo que nos afeta. Tradução Regina Lyra. Rio de Janeiro: Elsevier, 2007. p. 13.

44 Em tradução livre: "Juristas modernos cada vez mais freqüentemente baseiam suas análises não no pressuposto da racionalidade da economia neoclássica, mas no pressuposto de que os indivíduos estão sujeitos a uma série de tendências comportamentais sistemáticas. Esta própria suposição é fundamentada, em grande parte, por uma considerável literatura experimental documentando a racionalidade limitada, os erros de julgamento e as preferências fora do padrão" - WRIGHT, Joshua D. Behavioral Law and Economics, paternalism, and consumer contracts: an empirical perspective. NYU Journal of Law \& Liberty, v. 2, n. 3, p. 470-511, 2007. p. 471.

45 SUNSTEIN, Cass R. Behavioral law and economics. New York: Cambridge University, 2000.

46 Em tradução livre: "A cognição humana não é infinita" e "Nós temos habilidades computacionais limitadas e uma memória com graves falhas" - JOLLS, Christine et. al. A behavioral approach to law and economics. In: SUNSTEIN, Cass R. Behavioral Law and economics. New York: Cambridge University, 2000. p. 14.

47 Exemplificativamente, executivos muito ocupados processam extraordinariamente grandes quantidades de informação ao tomarem decisões e decidem quais assuntos merecem mais tempo e atenção. Esse processamento deve ser necessariamente simplificado, às vezes supersimplificado (simplista), para tornar as informações gerenciáveis, de modo a não permitir que o executivo seja esmagado por dados e paralisado pela ambigüidade. É o que pondera LANGEVOORT, Donald C. Organized Illusions: a behavioral theory of why corporations mislead stock market investors (and cause others social harms) In: SUNSTEIN, Cass R. Behavioral law and economics. New York: Cambridge University, 2000. p. 147. Levitt e Dubner citam Einstein para referir que "é preciso enxergar tudo o mais simplesmente possível", pois "por mais gratos que sejamos aos complexos processos que geraram tanta tecnologia e progresso, também ficamos tontos com sua atordoante proliferação. É fácil deixar-se seduzir pela complexidade; mas também há virtudes na simplicidade" LEVITT, Steven D.; DUBNER, Stephen J. Pense como um Freak. Tradução Clóvis Marques. Rio de Janeiro: 
o real comportamento humano destoa daquele padrão ideal pregado pelo modelo da racionalidade ilimitada, que pressupõe que todos ajam de acordo com o que, para a maioria, parece ser o mais benéfico para o agente e o mais correto para o todo. ${ }^{48}$ Ocorre que "human beings often take actions that they know to be in conflict with their own long-term interests". ${ }^{49}$

Nicole Chardin ${ }^{50}$, estudiosa das limitações à autonomia privada e ao autocontrole, explica que a autonomia da vontade é um princípio político oriundo de uma construção filosófica. Aponta ela as limitações à capacidade de manifestação volitiva racional, notadamente em uma sociedade como a atual em que há uma abismal diferença informacional entre as pessoas, tanto físicas quanto jurídicas, afirmando que indivíduos são levados a contratar induzidos por fatores externos enquanto creem estar agindo com autodeterminação. A vontade só estaria presente quando não há automatismo, nem simples impulso (ato reflexo, impensado) e nem influência de fatores externos.

Nem sempre, porém, dispomos de tempo e informações para as reflexões necessárias ao processo de tomada de decisão racional:

Diante de situações nas quais o custo de uma decisão exata é elevado em relação aos benefícios imediatos esperados, as pessoas costumam fazer uma "avaliação subjetiva de probabilidade" usando atalhos mentais para decidir por aproximação. Estes atalhos mentais são denominados na doutrina econômica como heurísticas. Esta forma de agir pode denotar uma conduta racional de simplificação, como exposto acima, ou pode ter como causa o fato de que as pessoas não possuem a informação ou o treinamento necessário para decidir da forma correta. ${ }^{51}$

Em muitos casos, as certezas que servem de premissa para a decisão ou não estão corretas, ou estão incompletas.

Segundo Maule e Hodgkinson (2002), o ponto de partida para as teorias sobre julgamento e tomada de decisão é o fato de que as pessoas têm capacidade limitada para o trabalho mental. Para lidar com um mundo complexo e marcado por rápidas mudanças, as pessoas desenvolveram modos simples de raciocinar. No que tange ao julgamento e tomada de decisão, as heurísticas assumem o papel de simplificar o processamento cognitivo que envolve julgar alternativas sob incerteza. ${ }^{52}$

O processo de tomada de decisões é fruto de avaliação das alternativas, com base em processos mentais denominados de ajustamento, ancoragem, disponibilidade e representatividade.

O "ajustamento" insuficiente decorre das imperfeições próprias da recuperação de informações. Exemplificativamente, "em algumas situações, a facilidade com que um determinado fato é lembrado ou imaginado pelo indivíduo pode determinar uma hiper ou subestimação da probabilidade ou frequência desse evento ocorrer. Dessa forma, as pessoas julgam essa probabilidade pela facilidade de evocar exemplos em suas memórias. ${ }^{" 53}$ Essas probabilidades subjetivas têm função determinante nas tomadas de decisão, uma vez que as pessoas costumam valer-se das heurísticas em detrimento das reais leis da probabilidade.

A “ancoragem" baseia-se na noção de meio-termo, ${ }^{54}$ pois, em uma decisão, partimos de dois extremos que

Record, 2014. p. 96.

48 JOLLS, Christine et. al. A behavioral approach to law and economics. In: SUNSTEIN, Cass R. Behavioral Law and economics. New York: Cambridge University, 2000. p. 14.

49 "Os seres humanos muitas vezes praticam ações que sabem estar em conflito com seus próprios interesses a longo prazo" (Tradução do autor) JOLLS, Christine et. al. A behavioral approach to law and economics. In: SUNSTEIN, Cass R. Behavioral Law and economics. New York: Cambridge University, 2000. p. 15.

50 CHARDIN, Nicole. Le contrat de consommation de crédit et l'autonomie de la volonté. Paris: LGDJ, 1988. p. 37.

51 FLORES FILHO, Edgar Gastón Jacobs; RIBEIRO, Rita de Cássia. Racionalidade limitada do consumidor e assimetria de informação. Economic Analysis of Law Review, v. 3, n. 1. p. 109-121, jan./jun. 2012. p. 110.

52 TONETTO, Leandro Miletto et al. O papel das heurísticas no julgamento e na tomada de decisão sob incerteza. Estudos de Psicologia, Campinas, v. 23, n. 2, p. 182-183, abr./jun. 2006.

53 TONETTO, Leandro Miletto et al. O papel das heurísticas no julgamento e na tomada de decisão sob incerteza. Estudos de Psicologia, Campinas, v. 23, n. 2, p. 184, abr./jun. 2006.

54 No segundo capítulo de seu livro, Dan Ariely explica o modo pelo qual se manipula facilmente a lei da oferta e da procura 
consideramos prováveis e optamos pelo que mais se aproxime de nossa informação âncora ${ }^{55}$, isto é, um valor que julgamos indicar o norte para a opção "correta". ${ }^{56}$

Isso se deve muito à aversão a extremos que é intrínseca aos indivíduos. Considere-se o seguinte exemplo: um comerciante tem alguns televisores de 30' que custariam $\mathrm{R} \$ 300,00$; muitos televisores de 40’ que custariam $\mathrm{R} \$ 500,00$ e alguns televisores de 50', que custariam $\mathrm{R} \$ 700,00$. Em condições normais, cada consumidor escolheria o modelo que lhe convém, considerando, também, os respectivos preços. Um comerciante conhecedor dos mecanismos que comandam o processo de tomada de decisão e que pretenda desovar o estoque de televisores de 40' colocaria estes a venda pelo preço que lhe corresponde $(\mathrm{R} \$ 500,00)$ e colocaria ao lado o televisor de 30’ ao preço de $\mathrm{R} \$ 400,00$ e o televisor de 50 ’ ao preço de $\mathrm{R} \$ 1.000,00$. Comparativamente aos outros, o televisor de 40' tornar-se-ia uma pechincha na cabeça do consumidor (é só um pouco mais caro que um modelo de tamanho menor e muito mais barato que um modelo de tamanho um pouco maior), embora tivesse ele pagando simplesmente o preço real do bem. Talvez ele nem precisasse de um televisor, mas é possível que venha a achar a oferta irresistível.

Isso ocorre porque, quando o sujeito raciocina a respeito de algo novo, instintivamente passa a compará-lo a algo semelhante, conforme as categorias já conhecidas. “A ‘âncora’ é o elemento já ‘conhecido’ que passa a influenciar o novo." ${ }^{57}$ Após o estouro da bolha imobiliária, em 2008, com as terríveis consequências para o setor securitário e bancário ${ }^{58}$, o governo norte-americano (Bush) interveio, injetando recursos bilionários nesses setores, para evitar sua quebra e alastramento para outros setores da economia. Pouco tempo depois, o povo americano, estarrecido, tomou conhecimento que parte desses recursos públicos estavam sendo usados para pagar salários e bônus milionários aos C.E.O.s dessas mesmas empresas, cujos montantes cresceram 32\% de 2009 para 2010. Em 2010, já no governo Obama, aprovou-se a lei Lei Dodd-Frank, reformando o sistema financeiro. Uma de suas disposições obrigava as empresas a divulgarem os salários e bônus de seus executivos. A ideia era que o constrangimento pelo recebimento de beneficiados custeados pelo contribuinte poderia contribuir para diminuir o valor das benesses. Todavia, o contrário aconteceu. Embora cada um deles estivesse satisfeito com seus salários, ao saberem que executivos atuando em empresas concorrentes do mesmo porte estavam ganhando benefícios maiores do que os seus, exigiram uma certa equiparação. Ou seja, em vez de se nivelar por baixo, nivelou-se por cima. Em valores absolutos, cada um estava satisfeito com os milionários salários que recebiam. Mas no momento em que tomaram conhecimento de uma "âncora" com a qual puderam comparar seus vencimentos (valores relativos), passaram a achar pouco o que ganhavam.

A “disponibilidade" é a capacidade de evocar exemplos em nossa memória ${ }^{59}$ para servirem ao ajustamento, com os fatos posteriores. Nos dizeres de Sternberg, é a "presença de informação armazenada na memória de longo prazo" . ${ }^{60}$ Assim, o que já aconteceu com (ou próximo a) alguém tende a ter um nível de ancoragem exagerado quando do cálculo de probabilidade.

criando valores âncora que induzem consumidores a crer no alto valor de um determinado produto. ARIELY, Dan. Previsivelmente irracional: como as situações do dia-a-dia influenciam as nossas decisões. Tradução Jussara Simões. Rio de Janeiro: Elsevier, 2008. p. 19-39.

55 Muitas vezes as pessoas fazem julgamentos de probabilidade, com base em um valor inicial, ou "âncora", para o qual fazem ajustes insuficientes - SUNSTEIN, Cass R. Behavioral law and economics. New York: Cambridge University, 2000. p. 5.

56 STARnBERG, Robert J. Psicologia cognitiva. Tradução Anna Maria Dalle Luche e Roberto Galman. São Paulo: Cangage Learning, 2010. p. 441.

57 OLSSON, Gustavo André. Análise econômica do direito penal e teoria sistêmica. Curitiba: Juruá, 2014. p. 174.

58 Segundo a Revista Exame, edição de 06/06/2011, “juntas, as 25 maiores instituições de Wall Street viram os lucros sair de 80 bilhões de dólares em 2006 para um prejuízo de 10 bilhões de dólares em 2008. Durante esse período, a remuneração nessas mesmas 25 empresas permaneceu inalterada" - disponível em https://exame.abril.com.br/revista-exame/tudo-como-antes-nos-salariosdos-executivos-americanos/2/, acesso em 25.05.2018.

59 As pessoas tendem a pensar que os riscos são mais graves quando um incidente prontamente é lembrado pela mente ou está 'disponível' - SUNSTEIN, Cass R. Behavioral law and economics. New York: Cambridge University, 2000. p. 5.

60 STARNBERG, Robert J. Psicologia cognitiva. Tradução Anna Maria Dalle Luche e Roberto Galman. São Paulo: Cangage Learning, 2010. p. 521. 
A disponibilidade é um dos fenômenos mais frequentes das heurísticas. Assim, se pedirmos para um grupo de pessoas estimar o grau de violência de sua cidade, por exemplo, muito provavelmente, as pessoas que já tiverem sido assaltadas, que já passaram por algum evento relacionado à violência urbana ou mesmo que tenham assistido a uma reportagem televisiva sobre o assunto irão avaliar o risco de agressão como sendo mais intenso do que aquelas que não tiveram nenhum tipo de experiência negativa nesse sentido. ${ }^{61}$

Desse modo, a proximidade de um evento tende a supervalorizar a recorrência deste. "Um erro judicial que o afete vai minar sua fé no sistema de justiça mais do que um incidente similar sobre o qual você tenha lido num jornal." ${ }^{62}$

Já a "representatividade" baseia-se na sensação de que tudo o que é similar trará resultados próximos. Um acontecimento passado é tido como uma pista sobre o que pode ocorrer no futuro.

Um exemplo de uso incorreto desse meio ocorre quando se deixa de observar se aquilo que causa a similitude é objetivamente irrelevante. Assim, quando alguém ganha um pequeno prêmio em uma rifa, tende a se considerar com sorte, partindo para um jogo de loteria com prêmios maiores, crendo que sua probabilidade de êxito esteja em alta diante do ganho anterior. A verdade é que, matematicamente, a cada jogo suas chances recomeçam sem qualquer influência do jogo anterior, por mais que ambos sejam jogos de azar bastante próximos.

Outro fator importante é a sensação de otimismo ${ }^{63}$ intrínseca ao ser humano, ${ }^{64}$ o que o leva a falsas percepções da realidade e à tomada de decisões desfavoráveis aos seus interesses. ${ }^{65}$

Em estudo sobre a falência, Ron Harris e Einat Albin definem o otimismo como "a crença que as pessoas tem que eventos negativos da vida, que poderiam influenciar sua capacidade de pagar o empréstimo, não acontecerão com eles" ${ }^{\prime 6}$.

A ponderação entre o benefício momentâneo e o risco de fracasso futuro é feita de modo inexato, avaliando sua suscetibilidade ao risco por meio do otimismo. Esse comportamento é intrínseco ao ser humano que, segundo Kilborn, age de acordo com três fatores: frequência, novidade e importância. Por isso, se, recentemente, houve a queda de um avião, ainda que os riscos sejam os mesmos — ou até menores já que a atenção daqueles que trabalham no setor será redobrada —, as pessoas tendem a não se utilizar desse meio de transporte por um tempo. E não há argumento racional — tal como comprovar, matematicamente, que a proporção de acidentes fatais no trânsito é maior — que altere o comportamento daquele indivíduo. Somente quando os meios de comunicação e as pessoas de seu convívio deixarem de comentar o assunto, sua avaliação do risco mudará.

A proximidade do evento danoso, também, é fator que muda o comportamento, como apontado pela "disponibilidade". Portanto, enquanto não chegar ao seu conhecimento a ocorrência de um evento negativo

61 TONETTO, Leandro Miletto et al. O papel das heurísticas no julgamento e na tomada de decisão sob incerteza. Estudos de Psicologia, Campinas, v. 23, n. 2, p.185, abr./jun. 2006.

62 KAHNEMAN, Daniel. Rápido e devagar: duas formas de pensar. Rio de Janeiro: Objetiva, 2012. p. 167.

63 LANGEVOORT, Donald C. Organized Illusions: a behavioral theory of why corporations mislead stock market investors (and cause others social harms) In: SUNSTEIN, Cass R. Behavioral law and economics. New York: Cambridge University, 2000. p. 149. 64 Lúcida a constatação de Spinoza: "por natureza, somos constituídos de maneira a acreditarmos facilmente nas coisas que esperamos e, dificilmente, nas que tememos, e a estimá-las, respectivamente, acima ou abaixo do justo. É essa a origem das superstições que, em toda parte, afligem os homens" - SPINOZA, Benedictus de. Ética. Tradução Thomaz Tadeu. 2. ed. Belo Horizonte: Autêntica, 2013. p. 130.

65 Consumidores, por exemplo, consistentemente subestimam seu endividamento futuro devido a uma miscelânea de tendências comportamentais, tais como autocontrole imperfeito, descontos hiperbólicos, empréstimos parcelados, e sistematicamente subestimam a probabilidade de consequências negativas (por exemplo, a incapacidade de pagar suas dívidas) - WRIGHT, Joshua D. Behavioral Law and Economics, paternalism, and consumer contracts: an empirical perspective. NYU Journal of Law \& Liberty, v. 2, n. 3, p. 475, 2007.

66 HARRIS, Ron; ALBIN, Einat. Bankruptcy in light of manipulation in credit advertising: personal bankruptcy in the 21 st Century: emerging trends and new challenges. Theoretical Inquires in Law, p.7, july 2006. Disponível em: < http://www.westlaw.com>. 
próximo, subestimará o risco de sua ocorrência. Assim, ainda que diariamente a imprensa noticie o aumento no número de acidentes envolvendo motocicletas, enquanto um determinado motociclista não se envolver em um acidente ou não presenciar um, não considerará os riscos que seu meio de transporte possui.

No que tange ao consumo, somos bombardeados muito mais por informações a favor da compra do que contra. De um lado, pingam notícias sobre crises de liquidez, aumento dos níveis de insolvência e casos de dramas pessoais de quem não consegue superar suas dívidas. Por outro lado, há uma publicidade torrencial que procura nos convencer que podemos pagar determinado produto em suaves prestações, a começar em data muito distante, ou de que lucraremos com liquidações imperdíveis, mesmo que não tenhamos reais necessidades daquele produto.

Enfim, os indivíduos supervalorizam benefícios e riscos imediatos e desvalorizam benefícios e riscos futuros. Ambos os sentimentos estão presentes em uma compra a prazo, pois se obtém a vantagem imediata (compre agora) com um custo futuro (pague depois). Faz-se necessária enorme força de vontade para abandonar uma atividade de risco que traz prazeres imediatos. ${ }^{67}$

Também as influências sociais interferem na tomada de decisão, pois os sujeitos costumam se apegar a informações de outros indivíduos a quem consideram confiáveis, sem maiores verificações sobre a informação em si. A contemporânea influência dos youtubers sobre boa parte da população jovem, especialmente a de menor escolaridade, é um fenômeno que comprova essa percepção.

As rotinas são hábitos conscientes praticados pelos sujeitos na busca por previsibilidade. Há uma natural tendência à repetição de atitudes, mesmo que estas não sejam tão benéficas. Assim, por exemplo, vamos supor que alguém adote um determinado trajeto para ir de casa ao trabalho levando em conta, apenas, a beleza do caminho, em detrimento de outras formas de chegar ao mesmo destino de modo mais rápido. Após muito tempo repetindo o mesmo percurso, se um dia esse indivíduo se atrasar e precisar chegar o mais rápido possível ao trabalho, provavelmente, fará o mesmo percurso de sempre mudando, apenas, a velocidade empregada no deslocamento, em vez de adotar um dos outros caminhos mais curtos. Nesse diapasão, por receio de fugir ao conhecido, pessoas seguem caminhos mais tortuosos em vez daqueles que seriam os mais benéficos para a sua finalidade.

Essa atitude também pode ser vista no meio empresarial, quando empreendedores que repetem certas práticas por muitos anos negam-se a mudá-las, apesar de racionalmente perceber que novas práticas poderiam trazer ainda mais benefícios. A resistência a mudanças (noção do "sempre fiz assim”) acarreta apego a padrões que se transformam em dogmas absolutamente irracionais.

O modo como somos vítimas de estereótipos, também, é um indicador de irracionalidades:

O estereótipo é um modo de categorizar informações, na esperança de prever sensações. O cérebro não pode partir da estaca zero a cada nova situação. Ele precisa partir de algo que já tenha visto, por isso, os estereótipos não são intrinsecamente maus. Eles são atalhos em nossa eterna tentativa de compreender ambientes complicados. É por isso que temos a expectativa de que o idoso irá precisar de ajuda para usar o computador ou que o aluno de Harvard é inteligente. ${ }^{68}$

Assim, pressupomos certas características de alguém com base, unicamente, em indicadores externos altamente falíveis. Quanto mais interagimos com os indivíduos e percebemos suas características singulares, mais abandonamos os estereótipos ${ }^{69}$, fruto de suposições oriundas de nossa tendência em categorizar e classificar tudo.

67 KILBORN, Jason. Comportamentos econômicos, superendividamento; estudo comparativo da insolvência do consumidor: buscando as causas e avaliando soluções. In: MARQUES, Cláudia Lima; CAVALLAZZI, Rosângela Lunardelli (Coord.). Direitos do consumidor endividado: superendividamento e crédito. São Paulo: Revista dos Tribunais, 2006. p. 67-78.

68 ARIELY, Dan. Previsivelmente irracional: como as situações do dia-a-dia influenciam as nossas decisões. Tradução Jussara Simões. Rio de Janeiro: Elsevier, 2008. p. 135.

69 MLODINOW, Leonard. Subliminar: como o inconsciente influencia nossas vidas. Tradução Claudio Carina. Rio de Janeiro: Zahar, 2013. p. 190. 
Por outro lado, apesar da busca racional pela verdade objetiva ${ }^{70}$, nosso cérebro distorce os fatos sem que percebamos, para chegar às conclusões que pretendemos. Investigamos, observamos, reunimos evidências e descobrimos padrões, mas ao mesmo tempo o cérebro, para raciocinar, busca antigas conclusões visando analisar os dados colhidos. Essa investigação é permanente, por isso colocamos à prova nossas conclusões, comparando-as com novos dados. Isso significa que o cérebro pode partir de evidências e chegar a conclusões, ou chegar a conclusões e buscar evidências que as comprovem. Ocorre que tal raciocínio esquece a natural propensão de ignorar ou menosprezar o que não se quer ver, assim, há uma tendência em nos agarrarmos a certas conclusões que nos parecem importantes e buscamos argumentos para comprová-las. Portanto, o "pensamento humano tende de forma consciente a partir da crença para a evidência, não vice-versa." ${ }^{71}$ Leonard Mlodinow, citando Johathan Haidt, afirma que "há duas maneiras de chegar à verdade: a maneira do cientista e a do advogado. A mente humana foi projetada para ser tanto cientista quanto advogado, tanto um buscador consciente da verdade objetiva quanto um advogado inconsciente e apaixonado por aquilo em que quer acreditar. [...] Podemos dizer que o cérebro é um bom cientista, mas é um advogado absolutamente brilhante." 72

Dificilmente alguma heurística estará baseada em uma racionalidade perfeita, pois as pessoas físicas nunca conseguirão abstrair fatores emocionais que limitam a decisão racional. Não se trata de concluir que o consumidor toma decisões irracionais. Elas são dotadas de uma certa racionalidade, porque obedecem a uma lógica. A questão central é que essa lógica é previsível e passível de identificação e manipulação por quem detém as informações sobre como tudo isso se processa. Independentemente da escolha do consumidor ser ou não racional, as decisões dos fornecedores, ao adotarem as técnicas de vendas, sempre serão mais pensadas do que a do consumidor que cotidianamente contrata com base em heurísticas, isso é, por meio de uma lógica facilmente identificável por aqueles que buscam meios eficientes de provocar o consumo. A assimetria de informação ${ }^{73}$ permite que aquele que vende selecione as informações que serão repassadas àquele que compra, fornecendo uma proposta em um formato que provoque a decisão de assumir a obrigação.

Merece, também, atenção o que cientistas chamam do mecanismo mental denominado "aversão à perda". Trata-se de um hábito mental que nos conduz a evitar decisões que impliquem perdas. Diante de possibilidades de perdas e ganhos, o cérebro se concentra, automaticamente, muito mais na perda, do que no ganho. Assim, diante da hipótese de uma perda imediata, mas com maior ganho compensatório posterior, frente a outra que apresente um ganho posterior inferior, mas sem a perda inicial, o cérebro tenderia a evitar a perda imediata, ainda que, no resultado final, a primeira opção fosse racionalmente mais vantajosa. Poderíamos pensar que isso nos levaria, portanto, a gastar menos. Todavia, outra tendência, já apontada, é aquela que nos leva a supervalorizar ganhos imediatos, em detrimento de despesas futuras. O cartão de crédito é, nesse caso, o instrumento perfeito para estimular um consumo irresponsável. ${ }^{74}$

É claro que esses achados não significam que a noção de livre-arbítrio não tenha mais valor ou sentido. Tal noção é imprescindível para a manutenção da convivência social, pois o mundo, tal como o conhecemos, entraria em colapso se, a partir desses achados, pudéssemos impunemente matar ou roubar com base no argumento simplista que 'meu cérebro mandou fazer isso ${ }^{75}$, ou se pudéssemos simplesmente desistir de

70 TARUFFO, Michele. Uma simples verdade: o juiz e a construção dos fatos. Tradução Vitor de Paula Ramos. Madri: Marcial Pons, 2012. STRECK, Lenio Luiz. Verdade e consenso. Rio de Janeiro: Lumen Juris, 2009.

71 MLODINOW, Leonard. Subliminar: como o inconsciente influencia nossas vidas. Tradução Claudio Carina. Rio de Janeiro: Zahar, 2013. p. 237.

72 MLODINOW, Leonard. Subliminar: como o inconsciente influencia nossas vidas. Tradução Claudio Carina. Rio de Janeiro: Zahar, 2013. p. 237.

73 ZYLBERSZTAJN, Décio; SZTAJN, Rachel. (Org.). Direito e economia: análise econômica do direito e das organizações. Rio de Janeiro: Elsevier, 2005. p. 121-130.

74 RAMOS, Fabiana D’Andrea. Superendividamento maior é problema do mercado de crédito, não do consumidor. 2017. Disponível em: $<$ https://www.conjur.com.br/2017-ago-16/garantias-consumo-superendividamento-maior-problema-mercado-credito-nao-consumidor>. Acesso em: 28 maio 2018

75 Seria como absolver Meursault, a personagem principal de "O estrangeiro", romance do absurdo, de Albert Camus, que com- 
nossos compromissos contratuais, alegando que nosso nível real de consciência sobre o ato praticado era muito reduzido.

Todavia, se é verdade que a relativização do livre-arbítrio não significa, necessariamente, um afrouxamento da responsabilização civil e penal que está vinculada às nossas condutas, também é verdade que esses novos conhecimentos necessariamente devem ser levados em conta para uma nova interpretação da noção do voluntarismo - a ideia de que assumimos responsabilidades, contratuais e extracontratuais, em razão de nossas vontades livremente manifestadas, lícita ou ilicitamente.

Passa-se a analisar, então, algumas das aplicações dessas noções e como elas impactam nosso cotidiano e quais as possíveis respostas do Direito ao fenômeno.

\section{IMPACtOS DE UM LIVRE-ARBítRIO RELATIVIZADO NA VIDA DE RELAÇÃo E No DiREITO}

Usando suas habilidades — inatas ou desenvolvidas — o homem manipula e controla o meio circundante para obter aquilo que almeja. Hoje, sua meta é vender, pois a sociedade capitalista em que vivemos autoalimenta-se do ciclo de produção - consumo de bens e serviços. O pleno emprego depende do consumo. Estimulando-se este, garante-se aquele. Sabe-se hoje que aromas, sons, cores e luzes hipnotizam o consumidor, que é levado a consumir por fatores que em nada se relacionam com a racionalidade da escolha. Assim, por exemplo, carros esportivos remetem ao aroma de borracha, carros de luxo, ao de couro. ${ }^{76}$

É evidente que não há como impedir o uso do conhecimento sobre processos anímicos do consumidor e sobre as limitações cognitivas que o tornam suscetível a induções e sugestionamentos. Uma das soluções para esse impasse, portanto, consiste em considerar o mínimo possível as manifestações volitivas dos consumidores que lhes sejam prejudiciais, notadamente quando a sua vontade se limita à aceitação de condições desfavoráveis previamente fixadas pelo fornecedor em contratos de adesão ${ }^{77}$, interpretando-se com generosidade o conceito e extensão de cláusulas abusivas. O simples fato de alguém ter assinado um contrato não significa que, efetivamente, tenha tomado conhecimento efetivo de todas as suas cláusulas e estivesse consciente de suas implicações jurídicas. A manifestação de uma vontade concordante, em muitas situações, deve ser vista, apenas, como uma ficção jurídica necessária para transformar aquele contato social num negócio produtor de efeitos jurídicos — criação de deveres para ambas as partes. Quando, posteriormente, se percebe que alguns desses deveres são altamente gravosos para a parte vulnerável — normalmente o consumidor —, não há como simplesmente se afirmar que se está diante de um contrato e que, portanto, pacta sunt servanda. Compreende-se, melhor, assim, o alcance e necessidade de conceitos e institutos como o das cláusulas abusivas, no CDC, lesão e estado de perigo, no CC, bem como a possibilidade da atuação equitativa do juiz (v.g., art. 413 do CC).

Uma aplicação evidente dessas ideias está consagrada no art. 49 do CDC, que reza:

Art. 49. O consumidor pode desistir do contrato, no prazo de 7 dias a contar de sua assinatura ou do ato de recebimento do produto ou serviço, sempre que a contratação de fornecimento de produtos e serviços ocorrer fora do estabelecimento comercial, especialmente por telefone ou a domicílio.

Parágrafo único. Se o consumidor exercitar o direito de arrependimento previsto neste artigo, os valores eventualmente pagos, a qualquer título, durante o prazo de reflexão, serão devolvidos, de imediato, monetariamente atualizados.

ete um homicídio absolutamente imotivado, induzido pelo calor e pela forte luz do sol da praia onde caminhava juntamente com a vítima, sem que fosse expressão de um querer consciente.

76 PEREIRA, Camila; TODESCHINI, Marcos. Anatomia do consumo. Revista Veja, São Paulo, 17 dez. 2008. Disponível em: <http://veja.abril.com.br/171208/p_090.shtml>. Acesso em: 16 jan. 2009.

77 WRIGHT, Joshua D. Behavioral Law and economics, paternalism, and consumer contracts: an empirical perspective. NYU Journal of Law \& Liberty, v. 2, n. 3, p. 493, 2007. 
Esse "prazo de reflexão" revela a percepção, do legislador, de que o consumidor muitas vezes compra por impulso, sendo suscetível a sugestionamentos. Se vínculos jurídicos obrigatórios devem decorrer de manifestação de vontades efetivamente conscientes, entende-se que o próprio legislador, antevendo situações em que essa reflexão consciente possa não inexistir, autorize a desistência do contrato, no exercício de um verdadeiro direito de arrependimento. Se, por um lado, é necessária a permanente preocupação com a estabilidade das relações jurídicas, por outro, é igualmente necessário que o legislador e o juiz estejam igualmente atentos aos reais interesses da parte vulnerável das relações jurídicas — não só consumidores —, protegendo-a de certas práticas negociais prejudiciais aos seus verdadeiros interesses, mas protegendo-a até mesmo de sua própria fraqueza humana. Uma interpretação generosa da exceção prevista no art. 49 do CDC, portanto, impõe-se.

Ainda na seara do consumidor, há já algumas décadas vem se intensificando a preocupação com o fenômeno do "superendividamento", ou seja, a assunção de obrigações superiores à capacidade de pagamento do devedor. No Brasil, Pesquisa de Endividamento e Inadimplência do Consumidor (Peic), apurada pela Confederação Nacional do Comércio, Bens, Serviços e Turismo (CNC) revelou que, em julho de 2017, $57,1 \%$ das famílias brasileiras estão endividadas; $24,2 \%$ estão com contas atrasadas e $9,4 \%$ não terão condições de pagar. ${ }^{78}$

O fenômeno exige uma reflexão profunda especialmente sobre as formas de concessão de crédito, especialmente por meio do mecanismo do crédito consignado. Esse mecanismo, em si interessante, com mais rápida concessão de crédito, com juros mais baratos, tornou-se uma das principais razões desse superendividamento. Uma oferta agressiva de tal tipo de crédito, especialmente a idosos aposentados, fez com que muitas vezes toda a família (filhos, netos) passasse a consumir mais do que o razoável e necessário, usando essa via. ${ }^{79}$

O fenômeno do superendividamento é tão preocupante que o próprio Poder Judiciário dele tomou consciência e procurou reagir, regulando formas de auxílio para quem se encontra em tal situação e procura sair dela. O Judiciário gaúcho (em iniciativa que também está presente em outros judiciários nacionais) institucionalizou a questão, constando do seu site oficial a seguinte página:

Superendividamento do Consumidor

\section{PRÁTICA DO TRATAMENTO DAS SITUAÇÕES DE SUPERENDIVIDAMENTO DOS CONSUMIDORES}

A reflexão e a tranquilidade do consumidor na avaliação da compatibilidade da dívida com a sua renda, antes de contraí-la é elemento determinante para evitar seu endividamento excessivo, também chamado de superendividamento. Este ocorre quando o consumidor gasta mais do que ganha ou quando sofre uma diminuição de seus rendimentos e passa a ter dificuldades de pagar as dívidas sem prejudicar as despesas de sobrevivência da família tais como aluguel, condomínio, alimentação, saúde, educação e transporte. Nesse caso, o prazer imediato da compra é substituído por restrições no orçamento familiar, sensação de frustração e até mesmo depressão. Este fenômeno já foi identificado e tutelado pela legislação em diversos países. Na vanguarda estão

78 RAMOS, Fabiana D'Andrea. Superendividamento maior é problema do mercado de crédito, não do consumidor. 2017. Disponível em: $<$ https://www.conjur.com.br/2017-ago-16/garantias-consumo-superendividamento-maior-problema-mercado-credito-nao-consumidor>. Acesso em: 28 maio 2018.Compartilhar

79 O fenômeno vem sendo objeto de muitas decisões judiciais, servindo de exemplo a seguinte: "AGRAVO DE INSTRUMENTO. SUPERENDIVIDAMENTO. Irresignação com o deferimento da antecipação dos efeitos da tutela que limitou os descontos ao percentual de $30 \%$ dos vencimentos brutos, excetuadas as verbas previdenciárias, os tributos obrigatórios e as pensões alimentícias, com determinação para expedição de ofício ao Órgão Pagador, a teor da súmula no 144 deste Tribunal. A decisão que limita o percentual de descontos a 30\% está amparada em súmula de jurisprudência predominante deste E. Tribunal de Justiça $\left(\mathbb{N}^{\circ} 295\right.$. "Na hipótese de superendividamento decorrente de empréstimos obtidos de instituições financeiras diversas, a totalidade dos descontos incidentes em conta-corrente não poderá ser superior a 30\% do salário do devedor.”). Como o autor é servidor público estadual e figuram no polo passivo da ação originária oito instituições financeiras é necessária a expedição de ofício ao órgão Pagador para que seja garantida a efetivação da medida. Aplicabilidade do art. 461, do CPC. Precedentes jurisprudenciais. RECURSO CONHECIDO. SEGUIMENTO NEGADO. (TJ-RJ - AI 00010336420168190000 , Data de publicação: 25/01/2016). 
países como França, Alemanha, Dinamarca, Suécia, Estados Unidos da América, entre outros. A falta de tutela legal a disciplinar medidas de atenuação ou de solução desta e a recorrente procura dos consumidores ao Poder Judiciário, através de ações revisionais no intuito de amenizar as consequências deste fenômeno de exclusão social, inspiraram a criação e a instalação de Projeto-piloto no Poder Judiciário do Rio Grande do Sul, hoje institucionalizado no Art. 1040 A da CNJ (Consolidação Normativa Judicial).

A prática é gratuita, independe da presença de advogado e viabiliza a renegociação conjunta das dívidas do consumidor e seus credores em único ato, de acordo com o orçamento familiar do superendividado. Para tanto, o requerente dispõe de um formulário padrão, onde declara dados pessoais sobre a renda e a extensão das despesas familiares, bem como a quantidade de credores, individualização destes e dados atinentes a cada uma das dívidas. $\mathrm{Na}$ oportunidade da entrega deste formulário, o consumidor já é notificado da data da audiência de renegociação. Os credores recebem cartas-convite com a advertência da necessidade de comparecimento com carta de preposição e poderes para conciliar.

Uma tentativa de despertar no consumidor a consciência de quanto pode estar sendo prejudicado em um negócio que envolva concessão de crédito foi albergada no art. 52 do CDC, verbis:

Art. 52. No fornecimento de produtos ou serviços que envolva outorga de crédito ou concessão de financiamento ao consumidor, o fornecedor deverá, entre outros requisitos, informá-lo prévia e adequadamente sobre:

I - preço do produto ou serviço em moeda corrente nacional;

II - montante dos juros de mora e da taxa efetiva anual de juros;

III - acréscimos legalmente previstos;

IV - número e periodicidade das prestações;

$\mathrm{V}$ - soma total a pagar, com e sem financiamento.

Preocupação do legislador também é notada na vedação prevista no art. 39, IV, do CDC:

Art. 39. É vedado ao fornecedor de produtos ou serviços, dentre outras práticas abusivas (Redação dada pela Lei no 8.884, de 11.6.1994) :

IV - prevalecer-se da fraqueza ou ignorância do consumidor, tendo em vista sua idade, saúde, conhecimento ou condição social, para impingir-lhe seus produtos ou serviços;

Outra importante aplicação da constatação da fragilidade da noção de livre-arbítrio encontra-se na potencial responsabilidade da indústria do fumo pelos danos causados aos fumantes. ${ }^{80}$ Nos Estados Unidos, o famoso relatório de 1964 do Surgeon General (Ministério da Saúde americano) tornou público que, do ponto de vista científico, era absolutamente incontroverso que o tabaco fazia muito mal à saúde ${ }^{81}$. Buscando neutralizar o impacto de tal relatório, a indústria tabagista procurou apoiar-se no mecanismo psicológico da racionalização e da negação utilizados pelos fumantes, como deixa claro memorando interno expedido pelo então Vice-Presidente Executivo da Philip Morris: "No futuro, devemos dar respostas que ofereçam aos fumantes uma muleta psicológica, uma racionalização para continuar fumando". Entre as 'muletas' e 'racionalizações' propostas constavam questões de teor médico, como 'mais pesquisas são necessárias' e 'existem contradições' e 'discrepâncias'. ${ }^{82}$

80 Especificamente sobre esse tema, remete-se o leitor a FACCHINI NETO, Eugênio. A relatividade do livre-arbítrio e a responsabilização da indústria do fumo: a desconstrução de um mito. Revista de Derecho Privado, Bogota, v. 31, p. 189-225, 2016.

81 Referido relatório teve um grande impacto na opinião pública norte-americana. Uma pesquisa de opinião realizada em 1958 demonstrou que, apenas, $44 \%$ dos norte-americanos acreditavam que fumar causava câncer, ao passo que tal percentual subiu para $78 \%$ em outra pesquisa realizada em 1968, sobre o mesmo tema, segundo informação colhida no artigo "The Reports of the Surgeon General - The 1964 Report on Smoking and Health”, publicado no site da National Library of Medicine, https://profiles.nlm. nih.gov/ps/retrieve/Narrative/NN/p-nid/60, acessado em 31.07.2016.

82 Informação contida no item 636 da sentença de 1672 páginas proferida pela juíza Gladys Kessler, na ação judicial movida pelos Estados Unidos contra as 11 indústrias fumageiras em atividade nos Estados Unidos (conhecida como United States v. Philip Morris et al.), proposta em 1999, julgada em primeiro grau em 2006 (já com trânsito em julgado) - Disponível em http://publichealthlawcenter.org/sites/default/files/resources/doj-final-opinion.pdf , acesso em 25.05.2018. 
Ou seja, a indústria do fumo, de forma deliberada e consciente, usou de todos os recursos psicológicos disponíveis para 'vender' seu produto, buscando quebrar as barreiras de uma saudável liberdade de escolha, neutralizando informações de que tal produto seria maléfico e fornecendo falsas 'muletas' para neutralizar os alertas cada vez mais abundantes e inequívocos provindos do meio científico.

A Economia Comportamental traz bons insights para esse debate:

[...] os seres humanos costumam selecionar, em tendo as opções possíveis, os argumentos que confirmam aquilo que eles previamente desejavam como conclusão.

[...] É de se reconhecer, por outro lado, que as seguintes afirmações são reconhecidamente corriqueiras entre os próprios fumantes: 'conheço alguém que fumou desde os 12 anos, hoje tem 90 e está bem' (utilizando um caso excepcional para confirmar a ideia que lhe convém, em detrimento de inúmeras pesquisas sérias que comprovam ser essa circunstância rara e que a grande maioria dos fumantes morre mal e prematuramente em razão do tabaco); 'fumo porque quero, paro quando quiser' (desconsiderando o caráter de vício do tabagismo e o fato de que a suposta 'escolha' que ele faz cotidianamente está longe de representar exercício de livre-arbítrio); 'quero parar de fumar, mas, só hoje, estou estressado, vou acender mais um cigarro' (comprovando a necessidade humana de satisfações instantâneas, em detrimento de maiores recompensas futuras); entre tantos outros exemplos possíveis" ${ }^{\prime 3}$.

O argumento do livre-arbítrio, costumeiramente invocado pela indústria do fumo, nas ações que buscam responsabilizá-la pelos danos à saúde dos fumantes, no sentido de que esses estão conscientes dos males que o fumo causa à saúde e, portanto, livremente decidiram fumar, revela-se, portanto, muito frágil, à luz daquilo que hoje se sabe sobre como o cérebro efetivamente funciona e sobre as formas como se pode influenciar comportamentos.

Pelas limitações inerentes a um artigo doutrinário, não há como aqui abordar todos os efeitos jurídicos ligados à constatação do déficit de racionalidade muitas vezes presente no processo de tomada de decisões, como as questões ligadas às revisões de cláusulas contratuais, proteção do idoso, na condição de sujeito hipervulnerável etc.

\section{Considerações finais}

O objetivo do presente trabalho foi demonstrar que, embora boa parte das instituições jurídicas se assente no pressuposto de que a pessoa humana é um ser racional, agindo livremente e conscientemente tomando decisões que geram efeitos jurídicos, os achados da psicologia comportamental e os desenvolvimentos da economia comportamental apontam para a constatação de que aquela pressuposição não pode ser tida como inabalável.

Os mecanismos psicológicos do processo de tomada de decisão revelam toda a fragilidade do ser humano e a sua dificuldade, muitas vezes, de tomar decisões efetivamente racionais. Determinadas escolhas que fazemos não são as que mais consultam nossos próprios interesses. Quem domina os achados das ciências que estudam o comportamento humano e o processo de tomada de decisão dos seres humanos pode, facilmente, influenciar comportamentos e induzir condutas.

Ainda que a necessidade da estabilidade das relações jurídicas exija que se possa confiar nas declarações de vontade 'livremente' emitidas, também um imperativo de justiça impõe que se deva proteger pessoas que, inconscientemente, foram levadas a praticar determinados atos, acreditando que estes eram fruto de sua vontade, quando, na verdade, foram induzidas a certos comportamentos.

Indicamos alguns desses casos e a resposta do direito aos mesmos, sem a pretensão de esgotá-los. Mas

83 OLIVEIRA, Amanda Flávio de; MOURA, Walter José Faiad de. É preciso proteger o fumante de si mesmo?. Revista Científica Virtual da Escola Superior da Advocacia da OAB-SP, São Paulo, n. 17, p. 162-163, inverno 2014. Edição especial: Direito e Tabaco. 
acreditamos que os casos brevemente referidos neste artigo são suficientes para demonstrar a necessidade de não se levar tão a sério o dogma do pacta sunt servanda, se quisermos realmente levar a sério a proteção da pessoa humana, percebida em toda sua fragilidade.

\section{REFERÊNCIAS}

ARIELY, Dan. Previsivelmente irracional: como as situações do dia-a-dia influenciam as nossas decisões. Tradução Jussara Simões. Rio de Janeiro: Elsevier, 2008.

BAUMAN, Zygmunt. Vida para o consumo: a transformação das pessoas em mercadorias. Tradução Carlos Alberto Medeiros. Rio de Janeiro: Zahar, 2008.

CARDOZO, Benjamin Nathan. The nature of the judicial process. In: A NATUREZA do processo e a evolução do Direito. Revista AJURIS, 1978.

CHARDIN, Nicole. Le contrat de consommation de crédit et l'autonomie de la volonté. Paris: LGDJ, 1988.

COMMONS, Michael Lamport; MILLER, Patrice Marie. Folk psychology and the law: why behavioral science needs to replace folk psychology. Revista Brasileira de Estudos Políticos, Belo Horizonte, n. 96, p. 7-30, jul./dez. 2007.

COMTE-SPONVILLE, André. Dicionário filosófico. Tradução Eduardo Brandão. São Paulo: Martins Fontes, 2003.

COSTA, Fernando Braga da. Homens invisiveis: relatos de uma humilhação social. São Paulo: Globo, 2004.

DARWIN, Charles. A origem das espécies por meio da seleção natural. Tradução André Campos Mesquita. São Paulo: Escala, 2009.

DEBORD, Guy. A sociedade do espetáculo. Tradução Estela dos Santos Abreu. Rio de Janeiro: Contraponto, 1997.

DESCARTES, René. Discurso do método. Tradução Paulo Neves. Porto Alegre: L\&PM, 2013.

DELEUZE, Gilles. Diferença e repetição. Tradução Luiz Orlandi e Roberto Machado. Lisboa: Relógio d’Água, 2000.

FACCHINI NETO, Eugênio. A relatividade do livre-arbítrio e a responsabilização da indústria do fumo: a desconstrução de um mito. Revista de Derecho Privado, Bogota, v. 31, p. 189-225, 2016.

SESSAREGO, Carlos Fernández. Trascendencia y reparación del "daño al proyecto de vida" en el umbral del siglo XXI. In: HERNÁNDEZ, Carlos Arturo et al (Org.). La Responsabilidad Civil. Bogotá: Universidad Libre, 2014. (Tendencias Contemporáneas del Derecho, v.19)

FERRY, Luc. Aprender a viver: filosofia para os novos tempos. Tradução Véra Lucia dos Reis. Rio de Janeiro: Objetiva, 2006.

FLORES FILHO, Edgar Gastón Jacobs; RIBEIRO, Rita de Cássia. Racionalidade limitada do consumidor e assimetria de informação. Economic Analysis of Law Review, v. 3, n. 1. p. 109-121, jan./jun. 2012.

HARARI, Yuval Noah. Sapiens: uma breve história da humanidade. Tradução Janaína Marcoantonio. 19. ed. Porto Alegre: L\&PM, 2017.

HARRIS, Ron; ALBIN, Einat. Bankruptcy in light of manipulation in credit advertising: personal bankruptcy in the $21^{\text {st }}$ Century: emerging trends and new challenges. Theoretical Inquires in Law, july 2006. Disponível em: $<$ http://www.westlaw.com>. 
HENRIQUES, Isabella. Controle do tabaco x controle do álcool: convergências e diferenciações necessárias. In: HOMSI, Clarissa Menezes (Coord.). Controle do tabaco e o ordenamento jurídico brasileiro. Rio de Janeiro: Lúmen Juris, 2011.

JOLLS, Christine et. al. A behavioral approach to law and economics. In: SUNSTEIN, Cass R. Behavioral Law and economics. New York: Cambridge University, 2000.

KAHNEMAN, Daniel. Rápido e devagar. duas formas de pensar. Rio de Janeiro: Objetiva, 2012.

KILBORN, Jason. Comportamentos econômicos, superendividamento; estudo comparativo da insolvência do consumidor: buscando as causas e avaliando soluções. In: MARQUES, Cláudia Lima; CAVALLAZZI, Rosângela Lunardelli (Coord.). Direitos do consumidor endividado: superendividamento e crédito. São Paulo: Revista dos Tribunais, 2006.

KANT, Immanuel. Crítica da razão pura. Tradução Lucimar A. Coghi Anselmi, Fulvio Lubisco. 3. ed. São Paulo: Ícone, 2011.

LANGEVOORT, Donald C. Organized Illusions: a behavioral theory of why corporations mislead stock market investors (and cause others social harms) In: SUNSTEIN, Cass R. Behavioral law and economics. New York: Cambridge University, 2000.

LEVITT, Steven. D.; DUBNER, Stephen J. Freakonomics: o lado oculto de tudo que nos afeta. Tradução Regina Lyra. Rio de Janeiro: Elsevier, 2007.

LEVITT, Steven D.; DUBNER, Stephen J. Super Freakonomics. New York: HarperCollins Publishers, 2009.

LEVITT, Steven D.; DUBNER, Stephen J. Pense como um Freak. Tradução Clóvis Marques. Rio de Janeiro: Record, 2014.

MLODINOW, Leonard. Subliminar: como o inconsciente influencia nossas vidas. Tradução Claudio Carina. Rio de Janeiro: Zahar, 2013.

NIETZSCHE, Friederich. Assim falou Zaratustra. Tradução Carlos Duarte e Anna Duarte. São Paulo: Martin Claret, 2012.

NIETZSCHE, Friederich. Crepúsculo dos idolos. Tradução Paulo César de Souza. São Paulo: Companhia das letras, 2006.

OLIVEIRA, Amanda Flávio de; MOURA, Walter José Faiad de. É preciso proteger o fumante de si mesmo?. Revista Cientifica Virtual da Escola Superior da Advocacia da OAB-SP, São Paulo, n. 17, inverno 2014. Edição especial: Direito e Tabaco.

OLSSON, Gustavo André. Análise econômica do direito penal e teoria sistêmica. Curitiba: Juruá, 2014.

PEREIRA, Camila; TODESCHINI, Marcos. Anatomia do consumo. Revista Veja, São Paulo, 17 dez. 2008. Disponível em: <http://veja.abril.com.br/171208/p_090.shtml>. Acesso em: 16 jan. 2009.

PINTO, Manuel da Costa (Org.). O Livro de ouro da psicanálise: o pensamento de Freud, Jung, Melanie Kein, Lacan, Winnicott e outros. 2. ed. Rio de Janeiro: Ediouro, 2007.

PUCHKIN, V. N. Heurística: a ciência do pensamento criador. Tradução Vera Neverova. Rio de Janeiro: Zahar Editores, 1969.

RABENHORST, Eduardo Ramalho. O valor da pessoa humana e o valor da natureza. In: MELGARÉ, Plínio; ALMEIDA FILHO, Agassiz. (Org.). Dignidade da pessoa bumana: fundamentos e critérios interpretativos. São Paulo: Malheiros, 2010.

RAMOS, Denise Gimenez; MACHADO JUNIOR, Pericles Pinheiro. Individuação e subjetivação: os conceitos junguianos de inconsciente coletivo e arquétipo mostram o caráter universal das imagens e dinâmicas 
do inconsciente que representam modos de estruturação da subjetividade no processo de individuação. In: PINTO, Manuel da Costa (Org.). O livro de ouro da psicanálise: o pensamento de Freud, Jung, Melanie Kein, Lacan, Winnicott e outros. 2. ed. Rio de Janeiro: Ediouro, 2007.

RAMOS, Fabiana D’Andrea. Superendividamento maior é problema do mercado de crédito, não do consumidor. 2017. Disponível em: <https://www.conjur.com.br/2017-ago-16/garantias-consumo-superendividamento-maior-problema-mercado-credito-nao-consumidor>. Acesso em: 28 maio 2018.

ROUSSEAU, Jean-Jacques. Discurso sobre a origem da desigualdade. Tradução Maria Lacerda de Moura. 2001.

RUSSELL, Bertrand. Ensaios céticos. Tradução Marisa Motta. Porto Alegre: L\&PM Editores, 2014.

SARTRE, Jean-Paul. O existencialismo é um humanismo. Tradução João Batista Kreuch. 3. ed. Petrópolis: Vozes, 2014.

SCHMIDT NETO, André Perin. Contratos na sociedade de consumo: vontade e confiança. São Paulo: Revista dos Tribunais, 2016.

SCHOPENHAUER, Arthur. O mundo como vontade e representação. São Paulo: Saraiva, 2001.

SCHOPENHAUER, Arthur. Sobre a vontade na natureza. Tradução Gabriel V. Silva. Porto Alegre: L\&PM, 2013.

SHAKESPEARE, William. Júlio César. 2000. Disponível em: < http://www.ebooksbrasil.org/eLibris/cesar. html>.

SPINOZA, Benedictus de. Ética. Tradução Thomaz Tadeu. 2. ed. Belo Horizonte: Autêntica, 2013.

STARNBERG, Robert J. Psicologia cognitiva. Tradução Anna Maria Dalle Luche e Roberto Galman. São Paulo: Cangage Learning, 2010.

SUNSTEIN, Cass R. Behavioral law and economics. New York: Cambridge University, 2000.

TARUFFO, Michele. Uma simples verdade: o juiz e a construção dos fatos. Tradução Vitor de Paula Ramos. Madri: Marcial Pons, 2012.

STRECK, Lenio Luiz. Verdade e consenso. Rio de Janeiro: Lumen Juris, 2009.

TONETTO, Leandro Miletto et al. O papel das heurísticas no julgamento e na tomada de decisão sob incerteza. Estudos de Psicologia, Campinas, v. 23, n. 2, abr./jun. 2006.

LLOSA, Mario Vargas. A civilização do espetáculo: uma radiografia do nosso tempo e da nossa cultura. Tradução Ivone Benedetti. Rio de Janeiro: Objetiva, 2013.

VEBLEN, Thorstein B. A teoria da classe ociosa: um estudo econômico das instituições. São Paulo: Pioneira, 1965.

WITTGENSTEIN, Ludwig. Investigações filosóficas. Tradução Marcos G. Montagnoli e Emmanuel Carneiro Leão. 9. ed. Petrópolis: Vozes; Bragança Paulista: Editora Universitária São Francisco, 2014.

WRIGHT, Joshua D. Behavioral Law and economics, paternalism, and consumer contracts: an empirical perspective. NYU Journal of Law \& Liberty, v. 2, n. 3, p. 470-511, 2007.

YARAK, Aretha. O livre-arbítrio não existe, dizem neurocientistas. Revista Veja. Disponível em: <https:// veja.abril.com.br/ciencia/o-livre-arbitrio-nao-existe-dizem-neurocientistas/>. Acesso em: 26 maio 2018.

ZYLBERSZTAJN, Décio; SZTAJN, Rachel. (Org.). Direito e economia: análise econômica do direito e das organizações. Rio de Janeiro: Elsevier, 2005. 
Para publicar na revista Brasileira de Políticas Públicas, acesse o endereço eletrônico www.rbpp.uniceub.br

Observe as normas de publicação, para facilitar e agilizar o trabalho de edição. 